\title{
Insights into rock-ice avalanche dynamics by combined analysis of seismic recordings and a numerical avalanche model
}

\author{
Demian Schneider, ${ }^{1}$ Perry Bartelt, ${ }^{2}$ Jacqueline Caplan-Auerbach, ${ }^{3}$ Marc Christen, ${ }^{2}$ \\ Christian Huggel, ${ }^{1}$ and Brian W. McArdell ${ }^{4}$ \\ Received 31 March 2010; revised 12 August 2010; accepted 30 August 2010; published 2 December 2010.
}

[1] Rock-ice avalanches larger than $1 \times 10^{6} \mathrm{~m}^{3}$ are high-magnitude, low-frequency events that may occur in all ice-covered, high mountain areas around the world and can cause extensive damage if they reach populated regions. The temporal and spatial evolution of the seismic signature from two events was analyzed, and recordings at selected stations were compared to numerical model results of avalanche propagation. The first event is a rock-ice avalanche from Iliamna volcano in Alaska which serves as a "natural laboratory" with simple geometric conditions. The second one originated on Aoraki/Mt. Cook, New Zealand Southern Alps, and is characterized by a much more complex topography. A dynamic numerical model was used to calculate total avalanche momentum, total kinetic energy, and total frictional work rate, among other parameters. These three parameters correlate with characteristics of the seismic signature such as duration and signal envelopes, while other parameters such as flow depths, flow path and deposition geometry are well in agreement with observations. The total frictional work rate shows the best correlation with the absolute seismic amplitude, suggesting that it may be used as an independent model evaluation criterion and in certain cases as model calibration parameter. The good fit is likely because the total frictional work rate represents the avalanche's energy loss rate, part of which is captured by the seismometer. Deviations between corresponding calculated and measured parameters result from site and path effects which affect the recorded seismic signal or indicate deficiencies of the numerical model. The seismic recordings contain additional information about when an avalanche reaches changes in topography along the runout path and enable more accurate velocity calculations. The new concept of direct comparison of seismic and avalanche modeling data helps to constrain the numerical model input parameters and to improve the understanding of (rock-ice) avalanche dynamics.

Citation: Schneider, D., P. Bartelt, J. Caplan-Auerbach, M. Christen, C. Huggel, and B. W. McArdell (2010), Insights into rock-ice avalanche dynamics by combined analysis of seismic recordings and a numerical avalanche model, J. Geophys. Res., 115, F04026, doi:10.1029/2010JF001734.

\section{Introduction}

[2] Large rock avalanches, ice avalanches, and mixed events have been documented for many of the glaciated regions of the world [Deline, 2001; Evans and Clague, 1988, 1998; Giani et al., 2001; Hewitt, 1999, 2009; Huggel et al., 2005, 2007, 2008a; Kääb et al., 2005; Korup, 2005; Lipovsky et al., 2008; Margreth and Funk, 1999; McSaveney, 2002; Schneider, 2006; Sosio et al., 2008]. Due to incomplete data for historical events, it is difficult to quantify the fre-

\footnotetext{
${ }^{1}$ Department of Geography, University of Zurich, Zurich, Switzerland. ${ }^{2}$ WSL Institute for Snow and Avalanche Research SLF, Davos-Dorf, Switzerland.

${ }^{3}$ Geology Department, Western Washington University, Bellingham, Washington, USA.

${ }^{4}$ Swiss Federal Institute for Forest, Snow and Landscape Research WSL, Birmensdorf, Switzerland.

Copyright 2010 by the American Geophysical Union. 0148-0227/10/2010JF001734
}

quency of large rock-ice avalanches, but it is possible that increases in event occurrence and magnitude can be expected due to changes in permafrost thermal state and the water cycle in connection with climate and glacier changes [Bottino et al., 2002; Davies et al., 2001; Fischer and Huggel, 2008; Gruber and Haeberli, 2007; Haeberli and Hohmann, 2008; Huggel et al., 2008b]. The events with the most catastrophic consequences during the last decades were the Huascarán (Peru, 1962: 650 casualties; 1970: 6000 casualties) [Evans et al., 2009a; Körner, 1983; Plafker and Ericksen, 1978] and the Kolka-Karmadon rock-ice avalanches (2002: 120 casualties) [Haeberli et al., 2004; Huggel et al., 2005; Kotlyakov et al., 2004]. Most rock-ice avalanches occur in remote regions with no or marginal infrastructure. However, population pressure, winter tourism development, and climate change can dramatically increase the risk for catastrophic events.

[3] Numerical models that calculate the flow path and deposition zones, or runout, are important tools for the investigation and back analysis of past events. They provide 


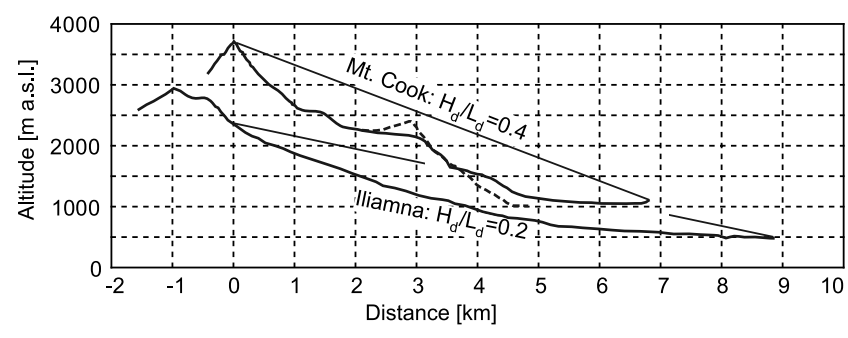

Figure 1. Comparison of height profiles from the 2003 Red Glacier avalanche at Iliamna volcano, Alaska, and the 1991 Aoraki/Mt. Cook avalanche, New Zealand. $H_{d} / L_{d}$ is the height to length ratio, and the straight line marks the start and end points of the avalanches. While the Iliamna profile approximates a parabola, the profile at Aoraki/Mt. Cook is much more complicated, with alternating steep and flat areas, runup on adverse slopes, and bifurcation of the runout path (dashed line is the secondary flow path).

insight into the complex processes occurring especially in large avalanches, which unlike snow avalanches [Sovilla et al., 2006; Suriñach et al., 2000] are problematic to trigger artificially and to perform in-flow measurements (we did not consider the artificial triggering of rock avalanches by nuclear explosions in this study [Adushkin, 2006]). There is a variety of different numerical mass movement models which can be roughly divided into empirical and physical models. For the current analysis, we need a physical model. These models are usually adapted to simulate the characteristic processes for a certain type of mass movement, e.g., for snow avalanches, rock slides, rock avalanches or debris flows. The events described in this study are challenging because at times they show flow characteristics similar to all of these processes, however, we call them generally "rock-ice avalanches." The choice of an appropriate model is difficult because none of the available models are able to simulate complex events with process transformations and interactions. Nevertheless, many authors pointed out similarities between flow types [e.g., Bouchut et al., 2008; Iverson and Denlinger, 2001; McDougall and Hungr, 2005]. The Voellmy rheology [Voellmy, 1955] was originally developed for the simulation of snow avalanches and already satisfyingly applied in several case studies of retrospective modeling of rock avalanches [e.g., Crosta et al., 2004; Hungr and Evans, 1996] and debris flows [e.g., Armento et al., 2008; Pirulli and Sorbino, 2008]. We used the two-dimensional dynamic physical model RAMMS (Rapid Mass Movements) which is based on the 2-D shallow water equations for granular flows and the Voellmy frictional rheology and test if it is able to reproduce the flow and deposition geometry as well as dynamic aspects of large rock-ice avalanches.

[4] Seismic stations in the vicinity to an avalanche event (approximately $<100 \mathrm{~km}$ ) can be used for early warning due to precursory seismicity in certain cases [Caplan-Auerbach et al., 2004], and many authors make use of seismograms of mass movement events to back-calculate total avalanche duration and velocity [Crosta et al., 2007; Lipovsky et al., 2008; McSaveney, 2002; McSaveney and Downes, 2002; Sosio et al., 2008]. However, seismograms do also contain valuable information about energetic and dynamic characteristics of the mass movement [Suriñach et al., 2005].
[5] The objective of this paper is to present a new approach for the combination of computational model results with seismic data to enhance the understanding of the dynamic (rock-ice) avalanche processes and to improve model calibration with a focus on geometric, energetic and dynamic characteristics of the modeled avalanche and the observed event. The paper indicates a possible linkage between modeled avalanche parameters and seismic data without the pretension to consider all aspects of the complexity of different mass movement types and seismic wave propagation. In particular, we explore the use of the seismic data to provide a physically based constraint on the frictional work rate predicted by the runout model, thereby resulting in a more realistic calibration of the model.

[6] First we give a short overview of the data and methods including the relationship between the computational runout model and the seismic data. Then, two avalanche events are presented as examples with very different topographic characteristics (Figure 1). The first is the 2003 Red Glacier avalanche at Iliamna volcano, Alaska, with a simple topography of a volcanic cone. There, runout is mostly straight and unconfined, with no significant vertical steps, runup, or lateral deflection of the avalanche. The second event is the Aoraki/ Mt. Cook avalanche of 1991 in the Southern Alps of New Zealand. This runout was characterized by various topographic steps, extensive runup, and strong lateral deflection, and we expect a more complex seismic signal. For both study areas we discuss the model input variables and problems related to different parameter combinations. Then we link the seismic records to the physical parameters calculated with the runout model (total momentum, total kinetic energy and total frictional work rate).

\section{Data}

\subsection{Topographic and Satellite Data}

[7] Both study areas are remote, necessitating the use of remote sensing data to estimate topography and the geometry of the avalanche path and deposits. The digital terrain model (DTM) for Iliamna Volcano in Alaska, was provided by the Shuttle Radar Topography Mission (SRTM) of February 2000 at a 1 arc second $(\sim 30 \mathrm{~m})$ resolution. The overall absolute vertical error of the SRTM-1 DTM is less than $16 \mathrm{~m}$ while the relative error which is relevant for the simulations is only $6 \mathrm{~m}$ [Rabus et al., 2003]. A map showing absolute vertical errors on all continents published by Farr et al. [2007] indicates errors of only $4 \mathrm{~m}$ for the Iliamna region. Despite possible rapid topographic changes in glacial environments, we assume that this data set adequately represents the preevent topography for the 2003 avalanche. We also used a satellite scene from the Advanced Spaceborne Thermal Emission and Reflection Radiometer (ASTER), dating from 9 August 2003, only 15 days after a large avalanche occurred on Red Glacier; outlines could be easily extracted. Oblique air photos taken during a USGS gas measurement flight at Iliamna volcano by Rick Wessels on 1 August 2003 were also helpful. Failure and deposit volumes were estimated by Caplan-Auerbach and Huggel [2007] and Huggel et al. [2007].

[8] For the Aoraki/Mt. Cook region in New Zealand, we used the NZ $25 \mathrm{~m}$ DTM derived from the NZ260 topographic map series at a scale of 1:50,000 which for the Aoraki/Mt. 


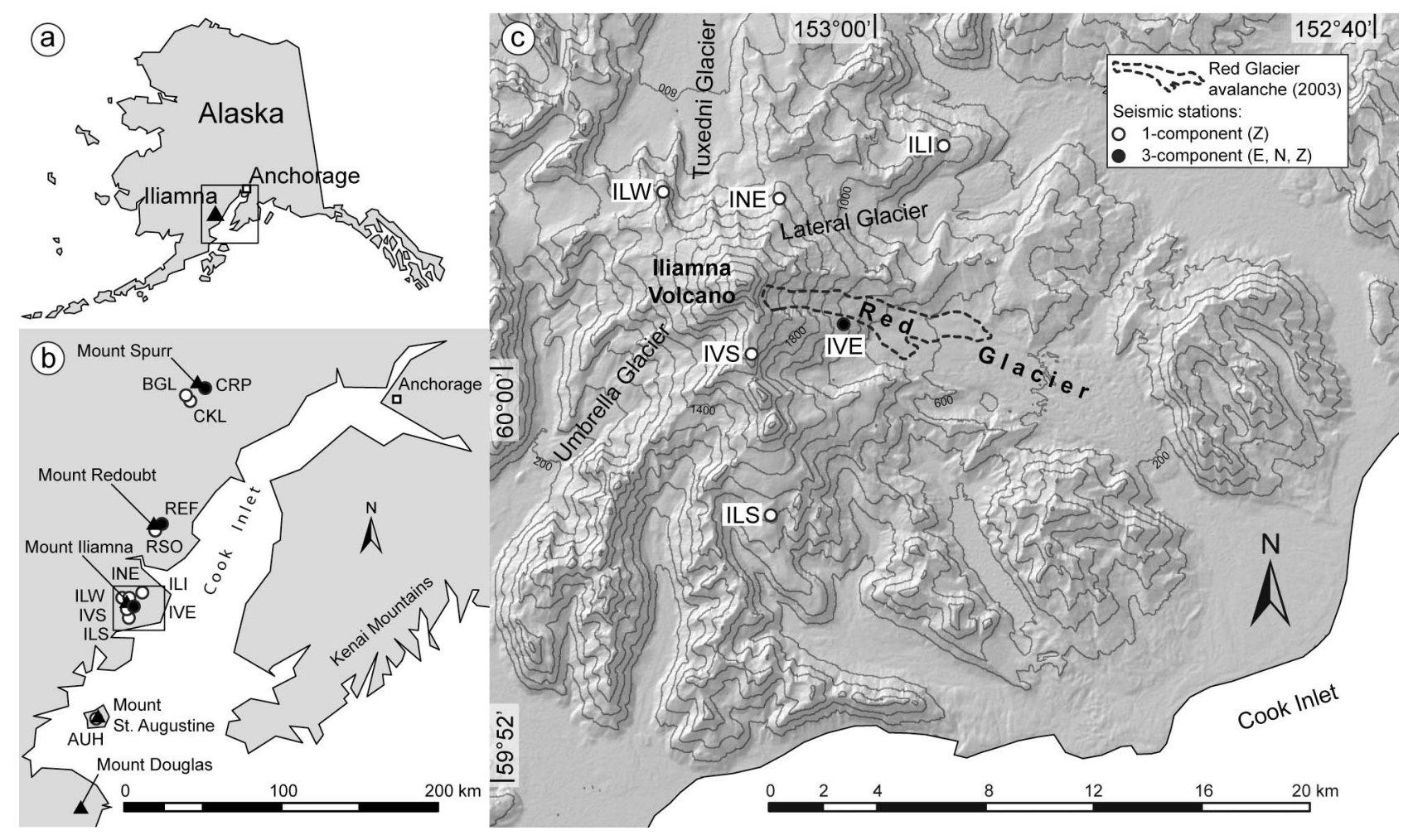

Figure 2. (a) Setting of Iliamna volcano in Alaska. (b) Location of the Alaska Volcano Observatory seismic network stations which were used in this study. Stations recording only vertical $(\mathrm{Z})$ ground motion are shown with a white circle (one-component stations). Those recording east $(\mathrm{E})$, north $(\mathrm{N})$, and vertical $(\mathrm{Z})$ movements are marked with a black circle (three-component stations). (c) Overview of the Iliamna region and the closest seismic stations. Dashed line shows the flow path outlines of the 25 July 2003 Red Glacier avalanche. Background map is the hillshaded SRTM-1 DTM.

Cook area is largely derived from 1986 imagery. The exception is the summit area of Aoraki/Mt. Cook, which is derived from January 1992 imagery specifically taken to correctly portray the new topography of the modified summit after the avalanche event. The topographic maps $(1: 50,000)$ and a more recent ASTER image of 24 January 2006 helped to localize the initiation area. The outlines of the 1991 rock-ice avalanche were digitized from McSaveney [2002]. Most of the information about erosion, dynamic behavior and deposition was taken from the same publication.

\subsection{Seismic Recordings}

[9] The Iliamna 2003 Red Glacier avalanche was recorded by the Alaska Volcano Observatory seismic network following approximately an hour of discrete earthquakes and a continuous tremor-like ground shaking. The $\sim 3$ min long broadband signal saturated all of the six seismometers on Iliamna, which are situated within epicentral distances less than $8 \mathrm{~km}$ at a broad azimuth range [Caplan-Auerbach and Huggel, 2007] (Figures 2 and 3). The avalanche signal exhibits a classic spindle shape with broadband $(1-20 \mathrm{~Hz})$ frequency content. The waveform envelope includes a small initial pulse lasting $\sim 20 \mathrm{~s}$ followed by a stronger signal that rises, saturates, and tapers over $\sim 100 \mathrm{~s}$. Seismograms recorded at epicentral distances of 51 (RSO) and $55 \mathrm{~km}$ (REF) on Redoubt volcano and at four more distant stations which are not saturated suggest a gradual increase and decrease for the part of the signal that is saturated at the Iliamna stations.
For this study we focus on the vertical component station ILS because it is the station with the smallest degree of saturation which is still situated on Iliamna, and approximately $7 \mathrm{~km}$ perpendicular (south) of the center of the Red Glacier avalanche flow path. We evaluated whether the recordings between $t=40 \mathrm{~s}$ to $t=80 \mathrm{~s}$ were amplified due to the avalanche's passing closer to the seismometer [Suriñach et al., 2000], but note that a similar increase in amplitude is observed on all stations, suggesting that the signal strength is a source rather than path effect. Station ILI is symmetrically situated on the opposite side of the avalanche path, and the seismogram is almost identical, suggesting that for this case, the path effects are negligible or at least homogeneously distributed over different directions and within a distance of 7-8 km. Seismograms of a series of geometrically similar large avalanches in 1997, 2000, 2003, and 2008 on Red Glacier [see Huggel et al., 2007] show very similar waveform envelopes. As Suriñach et al. [2000] state for artificially released snow avalanches, this indicates that large rock-ice avalanches of similar size following the same path and recorded at the same site produce similar seismic signals.

[10] The 1991 Aoraki/Mt. Cook avalanche was well detected up to distances exceeding $200 \mathrm{~km}$ (Figures 4 and 5). The nearest seismometer to the avalanche was short-period seismic station EWZ, located $58 \mathrm{~km}$ to the east of the mountain. The direction of the station is the same as the direction of avalanche movement, so we assume that during the event the signal amplitude increases continuously as the 

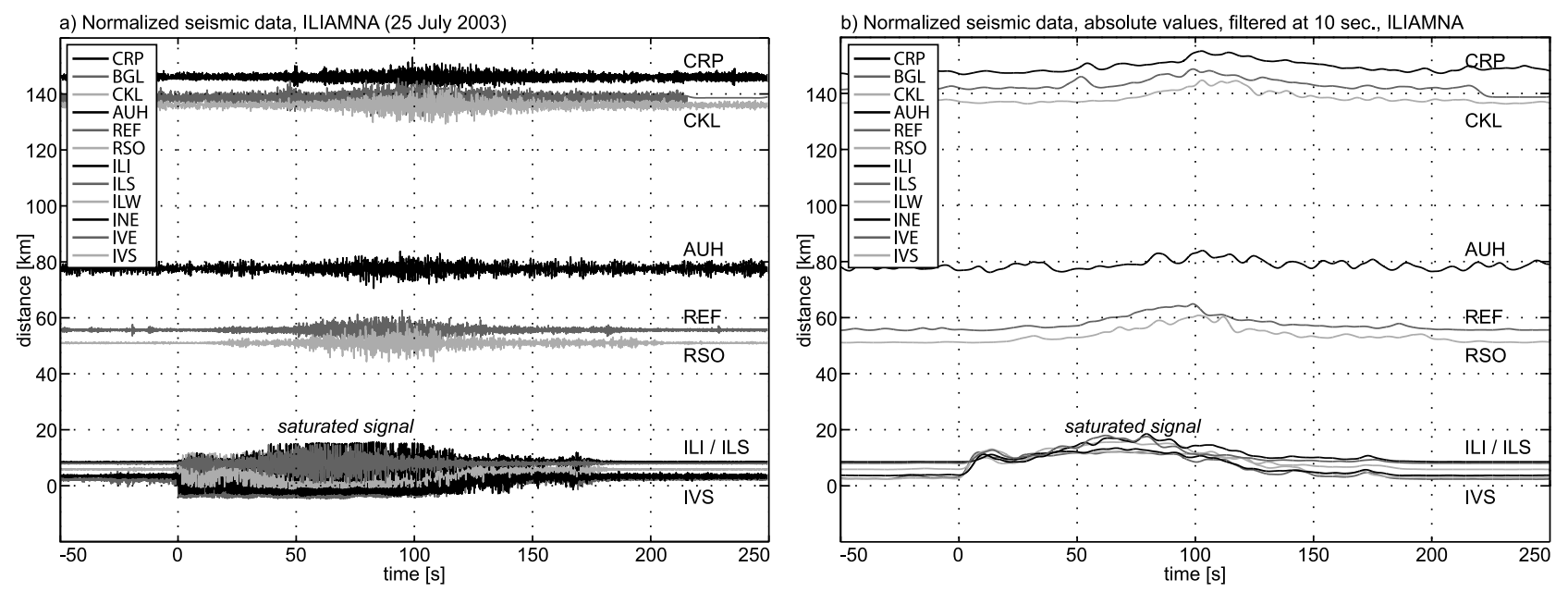

Figure 3. (a) Seismograms of the 25 July 2003 Red Glacier avalanche at Iliamna (Alaska) plotted against linearly increasing distance ( $y$ axis). Signal amplitude is given by normalized counts of the seismograph. (b) Amplitude envelopes of the data shown in Figure 3a. Absolute signal amplitude was low-pass filtered at $10 \mathrm{~s}(0.1 \mathrm{~Hz})$ to show long-period change in signal strength. Time $t=0 \mathrm{~s}$ is set to the arrival of the assumed first avalanche-induced seismic waves at station ILS. The shift in time of the seismographs with increasing distance is due to the travel time of the seismic waves in the ground. Station AUH is situated on Augustine volcano at $890 \mathrm{~m}$ asl on a very windy place, which might explain the high noise content.

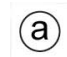

(a)
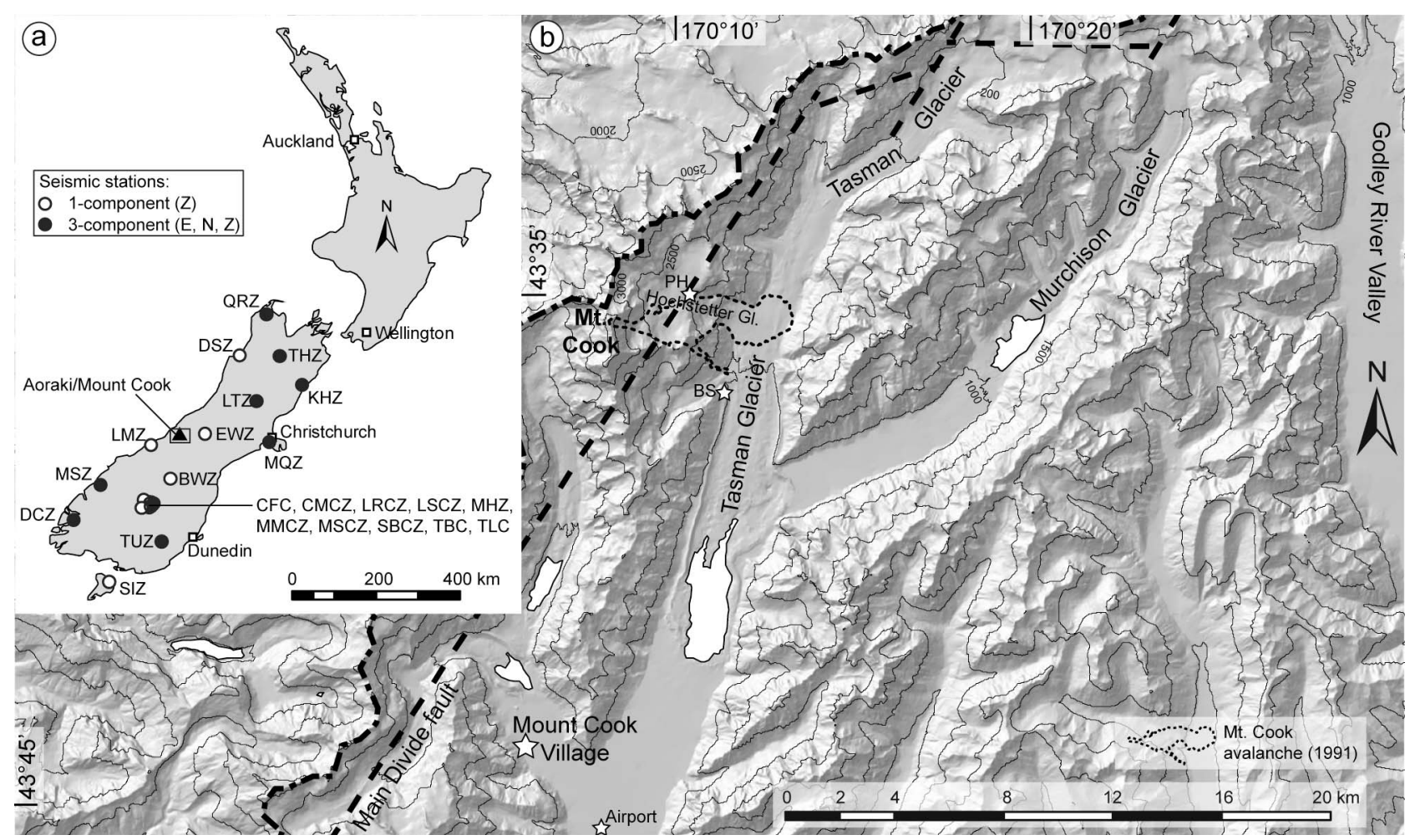

Figure 4. (a) New Zealand seismic network stations which were used in this study. Stations recording only vertical $(Z)$ ground motion are shown with a white circle (one-component stations). Those recording east (E), north (N) and vertical (Z) movements are marked with a black circle (three-component stations). (b) Setting of Aoraki/Mt. Cook (3754 m asl) and the 14 December 1991 rock-ice avalanche. White areas are (glacial) lakes mapped from the ASTER image from 24 January 2006. Dash-dotted line marks the Main Divide, and the dashed line marks the Main Divide fault. Note that the shape and size of the glacial lakes can change rapidly. Ball Shelter (BS) and the Plateau Hut (PH) are marked with white stars. Background map is the hillshaded NZ $25 \mathrm{~m}$ DTM. 

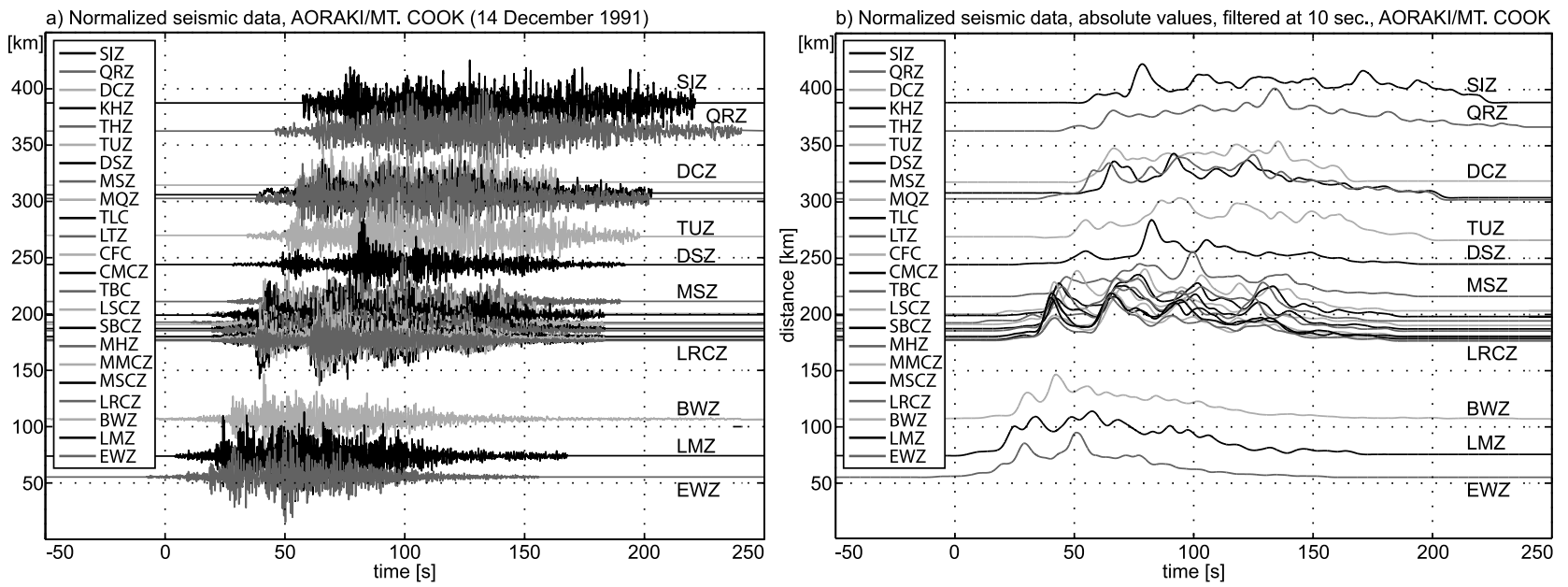

Figure 5. (a) Seismograms of the 14 December 1991 Aoraki/Mt. Cook avalanche (New Zealand) plotted against linearly increasing distance ( $y$ axis). Signal amplitude is given by normalized counts of the seismograph. (b) Amplitude envelopes of the data shown in Figure 5a. Absolute signal amplitude was also low-pass filtered at $10 \mathrm{~s}(0.1 \mathrm{~Hz})$ like in Figure $3 \mathrm{~b}$. Note that the straight line part of each seismogram is the centerline of the corresponding signal and the original data is missing there. Time $t=0 \mathrm{~s}$ is set to the arrival of the assumed first avalanche-induced seismic waves at station EWZ.

avalanche approaches the seismograph, however, due to the source-receiver distance this increase is likely negligible. Like the Iliamna signal, the Aoraki/Mt. Cook avalanche manifests as a spindle-shaped seismogram comprising several smaller pulses of energy. The duration of the signal at EWZ is $\sim 2$ min but the exact initiation and end times are difficult to determine. While station EWZ recorded only the vertical component of ground shaking, more distant stations were three-component (Figure 4). These stations show roughly equal amplitudes on all channels, suggesting that analysis of the vertical component at EWZ (and ILS for Iliamna) is a reasonable proxy for the total ground motion; however, some differences in amplitudes between horizontal and vertical components cannot be excluded [see also Suriñach et al., 2001]. The impacts of the avalanche on the topographic steps have generated bursts of high-frequency seismic energy which were more rapidly attenuated with increasing distance than the low-frequency signal portion. Energy distribution in the recorded spectra therefore changes with increasing distance, with the lower frequencies being better preserved. However, because the bulk of seismic energy generated by avalanches is low frequency [e.g., Caplan-Auerbach et al., 2004; Huggel et al., 2008a] the loss of high-frequency energy does not significantly affect our interpretations. The signal becomes also more extended in time, since $\mathrm{S}$ waves travel more slowly than $\mathrm{P}$ waves and wave distortions, reflections, scatterings and dispersions affect the envelope of the seismogram [Aki and Chouet, 1975]. These effects are visible in Figure 5, and therefore, the closest station EWZ is expected to best serve as the reference station for comparison with avalanche simulation data.

[11] At Iliamna, stations RSO and REF at distances of 51 and $55 \mathrm{~km}$ support the assumption that the (vertical) seismic signal still contains the basic source characteristics at least over a distance of around $60 \mathrm{~km}$ (Figure 3). We tried to identify specific phases within the waveform, but the nearest unsaturated three-component station RSO was at $55 \mathrm{~km}$ epicentral distance and exhibited a poor signal-to-noise ratio so that we were unable to identify them.

[12] The New Zealand stations which are further away from Aoraki/Mt. Cook than station BWZ $(107 \mathrm{~km})$ show high consistency between adjacent stations, but substantially more variation in the waveforms with growing distance, suggesting that path effects are larger. Because the only broadband station in New Zealand at that time was not digital, these data are not available and an analysis of the seismic energy generated by a possible rebound of the unloaded source as described by McSaveney [2002] (mainly long-period waves) was not considered in this study.

\section{Method}

\subsection{Numerical Simulation of Gravitationally Driven Mass Movements}

\subsubsection{Governing Differential Equations}

[13] To model (rock-ice) avalanche movement, the numerical model RAMMS (Rapid Mass Movements) solves the depth-integrated equations governing mass and momentum conservation in a two-dimensional, rectangular $x, y$ coordinate system [Christen et al., 2010b]. RAMMS has been used extensively in Switzerland to predict snow avalanche runout and flow velocities in general mountain terrain. We only describe the governing equations, a detailed presentation of the model and case studies are provided by Christen et al. [2010a, 2010b], and the second-order numerical solution of the governing differential equations is discussed by Kowalski [2008]. The mass balance of the avalanche at any position $x, y$ and time $t$ is given by

$$
\partial_{t} H+\partial_{x}\left(H U_{x}\right)+\partial_{y}\left(H U_{y}\right)=\dot{Q}(x, y, t)
$$

where $U(x, y, t)=\left(U_{x}(x, y, t), U_{y}(x, y, t)\right)^{T}$ with $T$ standing for the transpose of the matrix is the depth-averaged avalanche velocity, $H(x, y, t)$ the flow depth, and $Q(x, y, t)$ the entrainment 
rate in $\mathrm{m} \mathrm{s}^{-1}$. The volumetric entrainment rate in $\mathrm{m}^{3} \mathrm{~s}^{-1}$ can be calculated by multiplying $\dot{Q}$ with the cell area $A$, and if entrainment is absent, $\dot{Q}$ equals zero. A constant bulk flow density $\rho_{a}$ is assumed and the momentum balance is given by

$$
\partial_{t}\left(H U_{x}\right)+\partial_{x}\left(H U_{x}^{2}+\frac{g_{z} H^{2}}{2}\right)+\partial_{y}\left(H U_{x} U_{y}\right)=S_{g x}-S_{f x}
$$

and

$$
\partial_{t}\left(H U_{y}\right)+\partial_{y}\left(H U_{y}^{2}+\frac{g_{z} H^{2}}{2}\right)+\partial_{x}\left(H U_{x} U_{y}\right)=S_{g y}-S_{f y}
$$

where $g_{z}$ is the gravitational acceleration component perpendicular to the slope, $S_{g x}$ and $S_{g y}$ the slope-parallel gravitational acceleration forces and $S_{f x}$ and $S_{f y}$ the deceleration forces, respectively. Because the avalanche density $\rho_{a}$ is constant, the mass is represented by the flow depth $H$ and $S_{g x}$ and $S_{g y}$ are given by:

$$
S_{g x}=g_{x} H
$$

and

$$
S_{g y}=g_{y} H
$$

Although large rock-ice avalanches can reach flow depths $H$ of several decameters, they meet "shallow water" conditions since their horizontal extension is generally much larger.

\subsubsection{Frictional Resistance Model}

[14] The slope-parallel frictional deceleration forces $S_{f x}$ and $S_{f y}$ in $x$ and $y$ directions are given by the Voellmy model which combines dry Coulomb friction (coefficient $\mu$ ) with a velocitysquared dependent turbulent friction (coefficient $\xi\left[\mathrm{m} \mathrm{s}^{-2}\right]$ ) [Voellmy, 1955]:

$$
S_{f x}=\frac{U_{x}}{\sqrt{U_{x}^{2}+U_{y}^{2}}}\left[g_{z} H \mu+\frac{g\left(U_{x}^{2}+U_{y}^{2}\right)}{\xi}\right]
$$

and

$$
S_{f y}=\frac{U_{y}}{\sqrt{U_{x}^{2}+U_{y}^{2}}}\left[g_{z} H \mu+\frac{g\left(U_{x}^{2}+U_{y}^{2}\right)}{\xi}\right]
$$

The Voellmy model can therefore be used to simulate different stages of the avalanche motion, e.g., when the avalanche is moving slowly in the runout zone in a block-like motion (Coulomb friction dominates) or as a highly sheared, turbulent fluid in the acceleration zone (velocity-squared friction dominates).

[15] Although the Voellmy model is in widespread application in snow avalanche dynamics, its use remains somewhat in debate [Bartelt et al., 1999]. Despite efforts to physically quantify the values of $\mu$ and $\xi$ [Salm, 1993], they have not been experimentally verified. Calibrated values for extreme avalanches are available, but these are based on back calculation of events [Buser and Frutiger, 1980]. The Coulomb friction values used in numerical simulations are usually much smaller than the static, internal friction angle of the flow material. Similar problems arise in the application of the Voellmy model to rock avalanches [see Körner, 1976;
Kelfoun and Druitt, 2005]. However, independent experimental verification of Voellmy parameters has been reported from the snow avalanche community. Bartelt and Buser [2009] related the decrease in apparent Coulomb friction to the kinetic energy associated with the random movements of the snow granules and ice fragments which compose snow avalanches. They showed how the evolution of shearing within the avalanche body [Kern et al., 2009] can be modeled by accounting for the production and dissipation of the random kinetic energy [Bartelt et al., 2007; Buser and Bartelt, 2009]. At the head of the avalanche $\mu$ and $\xi$ values were found matching well accepted values for large avalanches $\left(\mu=0.155\right.$ and $\left.\xi=2000 \mathrm{~m} \mathrm{~s}^{-2}\right)$ [Bartelt and Buser, 2009]. At the avalanche tail, higher friction values were found which describes how avalanches run out of material (starve) or stop on steep slopes [Bartelt et al., 2007]. Because the Voellmy parameters seem to capture the movement of the avalanche front, they concluded that the Voellmy model can be applied to model runout distance and maximum flow velocity, but will have difficulties capturing the motion of the avalanche tail and thus modeling the spatial distribution of avalanche deposits.

[16] The Voellmy model, including the internal kinetic energy considerations described above, has been implemented in RAMMS together with a random kinetic energy extension [Buser and Bartelt, 2009] and successfully applied for different types of mass movements including snow avalanches [Christen et al., 2010a] and large rock avalanches [Preuth et al., 2010]. By setting the parameter for the production of random kinetic energy to zero, the frictional resistance reduces to the Voellmy model described in equations (4a) and (4b) [Christen et al., 2010b]. Because the focus of this paper is on the comparison between seismic data and modeled avalanche results, we concentrate on the well known and widely used Voellmy model [Bartelt et al., 1999].

\subsubsection{Entrainment of Material}

[17] The total moving volume of an avalanche usually does not remain constant: entrainment and deposition of material must be considered to correctly model the overall mass balance of a particular event. Large and rapid mass movements can cause extreme frontal and basal erosion leading to deposition volumes significantly larger than the failure volume [Fagents and Baloga, 2006; McDougall and Hungr, 2005; McSaveney, 2002]. In certain cases, the presence of an erodible ground layer can strongly increase the mobility of granular material [Mangeney et al., 2007], while in other cases the runout distance might be reduced due to momentum transfer from the moving mass to the static underlying erodible ground [McDougall and Hungr, 2005]. Crosta et al. [2009] made investigations focused on the water content of the entrained material. They found that eroded dry material generally reduces the total runout distance of debris avalanches while erosion of highly saturated material has more complex consequences. RAMMS includes the possibility to account for entrainment of a user specified potentially erodible ground layer of depth $h$, however, any resulting changes in surface topography are not considered.

[18] According to Hungr and McDougall [2009], entrainment can depend on slope, flow velocity, path curvature, surface roughness, or on characteristics and quantity of the erodible material (also proposed, e.g., by Sovilla et al. [2006] and Bouchut et al. [2008]). In their model DAN the erosion 
rate increases in proportion to the flow depth [Hungr and McDougall, 2009; McDougall and Hungr, 2005]. Others attribute erosion to the shear forces in the shear layer [Mangeney et al., 2007], fracture toughness [Cherepanov and Esparragoza, 2008] or, in the case of bedrock erosion of debris flows, to stresses due to granular interactions at the snout, strongly depending on the characteristic grain size [Hsu et al., 2008]. However, no definitive solution for a universal erosion model is available and implementation of different entrainment relationships in a numerical model as proposed by Hungr and McDougall [2009] is a reasonable approach to account for different entrainment types.

[19] In field studies of snow avalanche entrainment, the increase in mass was found to depend mainly on the avalanche velocity $U(x, y, t)$ and on the availability of snow mass [Sovilla et al., 2006, 2007]. Assuming a snow avalanche of constant flow density $\rho_{a}$ entraining an erodible snow layer of known depth $h$ and density $\rho_{e}$, the velocity-dependent entrainment rate $\dot{Q}_{U}$ is calculated as

$$
\dot{Q}_{U}=\frac{\rho_{e}}{\rho_{a}} k_{1} U
$$

[20] The erosion factor $k_{1}$ (dimensionless) needs to be calibrated to observations and controls the rate at which the erodible snow layer is incorporated and accelerated to the avalanche velocity. This regulates the mass uptake and time delay to accelerate the mass to the avalanche velocity. Details of the entrainment process and the numerical solution are presented by Christen et al. [2010b]. For snow avalanches, typically values between $k_{1}=0.2$ and 0.7 are used to match observed snow cover removal rates [Sovilla et al., 2006].

[21] Within a series of test runs with RAMMS we found that for snow, ice and rock avalanches larger than $10^{6} \mathrm{~m}^{3}$ which travel on potentially erodible layers much thicker than seasonal snow cover (e.g., entire glaciers or thick accumulations of loose debris in a glacier forefield) velocity-dependent erosion entrains too much material at the avalanche's tail. This effect is reduced by introducing the flow depth $H$ as an additional factor for scaling the entrainment rate as proposed by Fagents and Baloga [2006]. This results in an alternative momentum-dependent erosion $\dot{Q}_{p}$ :

$$
\dot{Q}_{p}=\frac{\rho_{e}}{\rho_{a}} k_{2} H U
$$

$\dot{Q}_{p}$ is called "momentum-dependent" erosion because the mass $m$ which is needed to calculate the momentum $p=m U$ is explicitly given by the product of the flow depth $H(x, y, t)$, the constant avalanche density $\rho_{a}$ and the calculation cell area $A$. Alternatively $\dot{Q}_{p}$ can also be called "discharge-dependent"; however, this terminology would more relate to dilute hyperconcentrated flows that are not investigated here. The erosion factor $k_{2}$ can be calibrated to field observations, but has the unit $\left[\mathrm{m}^{-1}\right]$ in this case. We found values between $0.14 \mathrm{~m}^{-1}$ and $0.25 \mathrm{~m}^{-1}$ to end in the desired deposition volumes. This approach has the advantage that erosion is concentrated in areas where avalanches have large flow depths and are moving relatively fast, such as the avalanche front where plowing can be a dominant mechanism [McDougall and Hungr, 2005; Sovilla et al., 2006]. Erosion is consequently attenuated behind the head of the avalanche, where flow depths and velocities are smaller, representing progressive basal erosion [Sovilla et al., 2006].

[22] Herein we compared the modeled erosion to field photographs and aerial and satellite images, as well as to reports concerning erosion and deposition in published field studies [e.g., Hungr and Evans, 2004]. The entrainment parameter $k_{2}$ for the momentum-driven erosion was iteratively calibrated to match the desired final deposition volume, and was thereafter held constant for each simulation.

\subsubsection{Total and Moving Volumes}

[23] The total volume $V_{\text {tot }}$ is the volume of the avalanche at each time step $t$ including the volume of eroded and already deposited material. The moving volume $V_{\text {mov }}$ is the amount of material that is still moving at a certain time step, according to a threshold value for the flow depth $H_{i}(t)$ and the flow velocity $U_{i}(t)$ (where $H_{i}(t) \geq 0.1 \mathrm{~m}$ and $U_{i}(t) \geq 1 \mathrm{~ms}^{-1}$ ) at each affected cell $i$ :

$$
\begin{gathered}
V_{\text {tot }}(t)=A \sum_{i=1}^{n} H_{i}(t) \\
V_{\text {mov }}(t)=A \sum_{i=1}^{n} H_{i}(t)
\end{gathered}
$$

where $n$ is the number of cells affected by the avalanche at time $t$ and $A$ the area of a single cell. If either the flow depth $H_{i}(t)$ or the flow velocity $U_{i}(t)$ falls below the threshold value, the material in the affected cell is defined to be not moving anymore.

\subsubsection{Model Evaluation and Optimization}

[24] For a given runout distance, there are various possible combinations of the friction parameters $\mu$ and $\xi$, as already shown by Perla et al. [1980] and Alean [1984] for the twodimensional case and by Pirulli and Sorbino [2008] for threedimensional terrain. We used a $\mu$ value from previous works (e.g., $\mu=0.05$ ) [Hungr and Evans, 1996; Lipovsky et al., 2008; Sosio et al., 2008], and iteratively searched for a $\xi$ value such that the modeled avalanche reaches the real runout distance. Then, we increase and decrease $\mu$ systematically in 0.01 steps to find the corresponding $\xi$ values. Possible $\mu \xi$ combinations that fit the runout distance describe an exponential function (Figure 6).

[25] We distinguished between geometry and dynamics of the results to assess the performance of the model. Geometry includes the avalanche release and deposition volumes, flow depths, the spatial extent of the avalanche path and thickness of deposited or eroded material. Model dynamics are restricted to the evolution of the avalanche's momentum and kinetic energy, work rate, the stopping characteristics, mean and maximum velocities, and special attributes such as runup, backflow, centrifugal effects, overtopping and flow bifurcation. The validation is complicated by the sparse data, making a strictly quantitative assessment not feasible. Instead, the model results have to be assessed to optimize the match between the modeled event and the limited amount of real avalanche data.

\subsection{Avalanche Model: Seismic Data Relation}

[26] The basic concept of linking the calculated model parameters and seismic data is that in a (rock-ice) avalanche potential energy is converted into kinetic energy, part of 


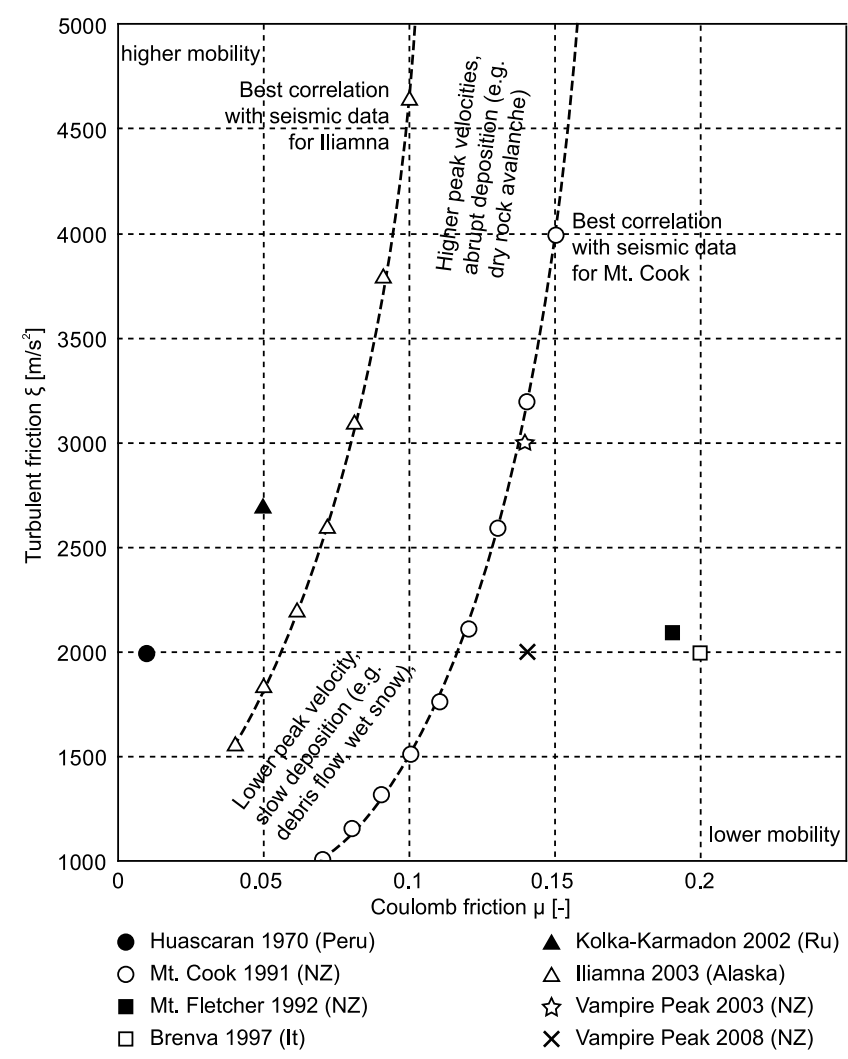

Figure 6. Graph modified after Allen et al. [2009]. Possible $\mu$ and $\xi$ input parameters for RAMMS model leading to the runout distance of the corresponding real event. For Iliamna and Aoraki/Mt. Cook, all parameter combinations that geometrically matched the observed flow path are shown on the dashed line which also indicates the exponential relationship of corresponding $\mu$ and $\xi$. The smaller the value of $\mu$ and the larger the value of $\xi$, the longer is the avalanche runout distance and vice versa. Smaller $\mu \xi$ combinations lead to slower deposition where decelerating avalanche parts keep moving with a very slow motion up to minutes. Larger $\mu \xi$ combinations show stronger acceleration during the early phase of the movement with higher peak velocities and a more abrupt stopping behavior.

which in turn is transformed into seismic energy due to interaction of the flowing mass of rock and ice with the ground [Brodsky et al., 2003; Davies and McSaveney, 1999; Deparis et al., 2008; Kanamori and Given, 1982; Kawakatsu, 1989; Sabot et al., 1998; Suriñach et al., 2001; Weichert et al., 1994]. Because the seismometer is not situated directly at the shear layer of the moving avalanche, the recorded seismic waves are transformed between source and receiver. We distinguish between the seismic source signal and a variety of source and path effects:

[27] 1. Seismic source signal: This is the seismic signal produced by the avalanche directly at the site of the event. The strength of the produced signal is related to the total momentum, respectively total kinetic energy of the avalanche (which in turn depend on mass and velocity, and hence also on entrainment [Suriñach et al., 2001, 2005]). Furthermore, the production of seismic energy is affected by the surface properties of the avalanche path which include surface roughness (on a millimeter to decameter scale), but also centrifugal and impact effects caused by minor and major obstacles, topographic steps and lateral deflections [McSaveney and Downes, 2002; Sabot et al., 1998; Suriñach et al., 2001]. All these components control the rate at which kinetic energy is transformed into heat, particle fragmentation [Crosta et al., 2007; Davies et al., 2007; Locat et al., 2006] and seismic waves.

[28] 2. Local source site effects: The substrate below the shear plane or at an impact site can have a strong effect on the efficiency of seismic wave transmission into the ground, e.g., moraine material, snow or glacier ice might attenuate the seismic signal compared to cohesive rock [Deparis et al., 2008].

[29] 3. Seismic path effects: Seismic waves can be attenuated, dispersed, scattered, refracted and reflected as they travel, in a manner dependent upon the characteristics of the material through which they propagate. This degrading effect is strongly dependent on the distance between source and receiver [Deparis et al., 2008] and the frequency of the seismic waves. The seismic waveform is also changed along the path due to variations in travel path of different seismic phases; because waves travel at a range of velocities their arrivals disperse at more distant stations [Aki and Chouet, 1975].

[30] 4. Local recorder site effects: As at the source, the seismic station can be affected by site specific effects which are controlled by the underlying ground (lithology, topography) [Surinach et al., 2001].

[31] To compare the recorded seismograms of large and rapid mass movements with numerical simulation results, the described site and path effects in the seismic data should be as small as possible. This is possible by using a case study with a simple topography such as Iliamna volcano, and by selecting the closest seismic stations (but which still are not completely saturated). Iliamna's simple topography prevents problems in quantifying the influence of steps, obstacles, lateral deflections, and changing surface roughness on the efficiency of seismic wave generation and we therefore assume that the seismic efficiency is more or less constant (this is clearly not the case for many other mass movements and has to be considered when analyzing the seismic signal). If the avalanche loses such a constant portion of its energy in the form of seismic waves to the ground, the recorded seismic signal of the avalanche should also be approximately proportional to the instantaneous total momentum $p_{\text {tot }}(t)$, and, respectively, total kinetic energy $k_{t o t}(t)$, which in the RAMMS model is calculated by

$$
\begin{aligned}
& p_{\text {tot }}(t)=A \rho_{a} \sum_{i=1}^{n} H_{i}(t) U_{i}(t) \\
& k_{\text {tot }}(t)=A \rho_{a} \sum_{i=1}^{n} H_{i}(t) U_{i}(t)^{2}
\end{aligned}
$$

In a strict sense, the seismic signal reflects the loss of avalanche power, not the remaining energy. The loss of power is described by the instantaneous total frictional work rate $\dot{W}_{\text {tot }}$,

$$
\dot{W}_{\text {tot }}(t)=A \rho_{a} g \sum_{i=1}^{n} U_{i}(t)\left[\mu H_{i}(t)+\frac{U_{i}(t)^{2}}{\xi}\right]
$$




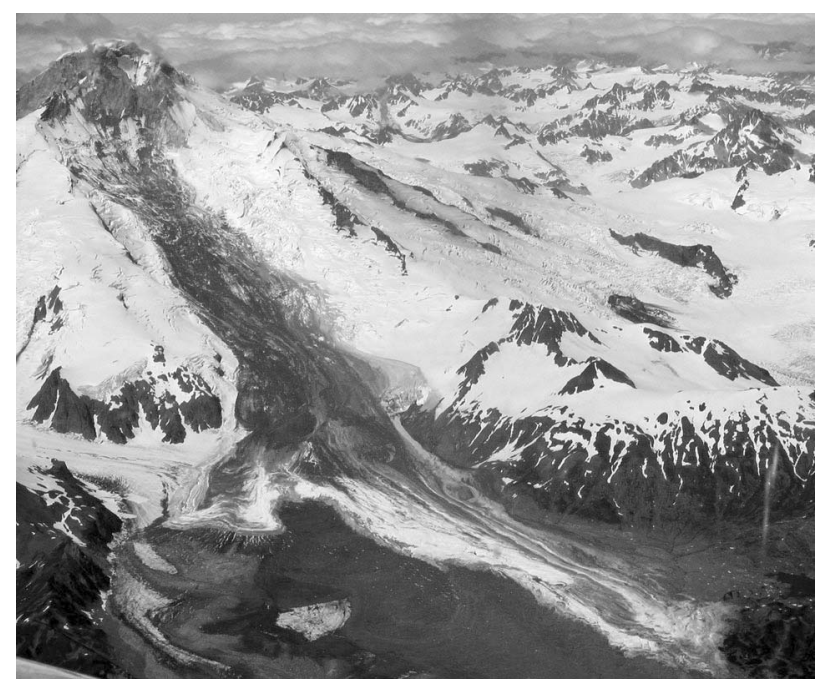

Figure 7. Oblique aerial view of the 25 July 2003 Red Glacier avalanche at Iliamna Volcano, Alaska. Dark color is evidence for basal rock entrainment from the upper part of the avalanche and remobilized debris from older rock-ice avalanche deposits on the glacier surface. Note lateral swashing in the orographically left central part of the avalanche. Photo by R. Wessels, USGS (1 August 2003).

where $g$ is the gravitational acceleration $\left(9.81 \mathrm{~m} \mathrm{~s}^{-2}\right)$. Equation (7c) depends on the applied frictional resistance model, which in this case is the Voellmy model with the friction parameters $\mu$ and $\xi$. The simple Voellmy model lumps all energy consuming processes into two simple constitutive parameters. It does not consider the kinetic energy of particle fluctuations and therefore the particle interaction with the basal boundary, which is the producer of seismic energy. However, because the momentum transfer between the avalanche and the ground is given by the total frictional work rate, we assume that the seismic energy generation is proportional to the total frictional work rate given by the Voellmy model. If the seismic signal is not strongly modified on its way to a seismometer (path effects), the measured seismic signal still should be proportional to the total frictional work rate of the avalanche.

[32] We compare all calculated parameters (from equations (7a), (7b), and (7c)) of a simulated avalanche to the absolute filtered amplitudes of the corresponding recorded seismic avalanche data. Major differences between these data sets may indicate differences in the energy consuming processes (e.g., the surface roughness) or local source and recorder site effects, as well as seismic path effects. Strong differences between modeled and recorded data can also indicate progressive and multiple failures of mass, which are much more complex and cannot be modeled accordingly.

\section{Iliamna Red Glacier 2003 Avalanche (Alaska)}

\subsection{Setting and Characteristics of Event}

[33] Iliamna volcano (3053 $\mathrm{m}$ above sea level (asl)) is an andesitic stratovolcano of the Aleutian arc in the Cook Inlet region of Alaska [Caplan-Auerbach and Huggel, 2007] (Figure 2). The volcanic edifice has developed over older plutonic rocks of Jurassic age [Detterman and Reed, 1980]. Field investigations by Waythomas et al. [2000] have shown that Iliamna has erupted at least twice during the last 300 years. On the east face, there is a zone of hydrothermally altered rocks with sulfurous fumaroles and frequent steam emissions [Huggel, 2009; Waythomas et al., 2000]. Directly below this area, Red Glacier extends from $2300 \mathrm{~m}$ asl to about $150 \mathrm{~m}$ asl. The lower boundary of Red Glacier is not clearly detectable because it is covered by debris and many small water bodies. Trabant [1999] estimated for Red Glacier a total ice volume of $4.7 \mathrm{~km}^{3}$ and an area of $52.5 \mathrm{~km}^{2}$.

[34] Since 1960, frequent and large ice-rock avalanches between $1 \times 10^{6} \mathrm{~m}^{3}$ and $3 \times 10^{7} \mathrm{~m}^{3}$ with return periods of only 2-4 years have been observed on the slopes of Iliamna volcano. The largest ones occurred on Red Glacier, all having a similar flow and deposition geometry [Caplan-Auerbach and Huggel, 2007; Huggel et al., 2007]. The best documented event, which took place on 25 July 2003, was selected for investigation. During this event, approximately $6 \times 10^{6} \mathrm{~m}^{3}$ of rock and ice detached at the upper boundary of Red Glacier at $2300 \mathrm{~m}$ asl (Figure 7). The average failure depth was estimated to be $10-15 \mathrm{~m}$ with the failure zone partly in ice, rock, and mostly at the ice-rock interface. The presence of rock in the initial mass is indicated by the dark color of the avalanche path and deposit (Figure 7). It is estimated that another 6-14× $10^{6} \mathrm{~m}^{3}$ of ice and debris deposits of older rock-ice avalanches were eroded on the way down where finally $12-20 \times 10^{6} \mathrm{~m}^{3}$ rock and ice debris were deposited [Huggel et al., 2007]. The vertical height difference $H_{d}$ of the avalanche path is $1800 \mathrm{~m}$ while the horizontal distance along the curved main avalanche path $L_{d}$ is $8800 \mathrm{~m}$, corresponding to an $H_{d} / L_{d}$ ratio of 0.2 (Figure 1 and Table 1 ). $H_{d}$ and $L_{d}$ are both related to the vertical and horizontal distance between the uppermost point of the detachment area and the lowest and most distant point of the avalanche deposit.

Table 1. Observed Characteristics of the Iliamna Red Glacier Avalanche (25 July 2003) and the Aoraki/Mt. Cook Avalanche (14 December $1991)^{\mathrm{a}}$

\begin{tabular}{|c|c|c|c|c|c|c|c|c|c|c|}
\hline Avalanche & $\begin{array}{l}\text { Failure } \\
\text { Elevation } \\
\text { (m) }\end{array}$ & $\begin{array}{l}\text { Drop } \\
\text { Height } \\
H_{d}(\mathrm{~m})\end{array}$ & $\begin{array}{l}\text { Runout } \\
\text { Length } \\
L_{d}^{\mathrm{b}}(\mathrm{m})\end{array}$ & $H_{d} / L_{d}$ & $\begin{array}{c}\text { Initial } \\
\text { Volume } \\
\left(10^{6} \mathrm{~m}^{3}\right)\end{array}$ & $\begin{array}{c}\text { Entrained } \\
\text { Volume } \\
\left(10^{6} \mathrm{~m}^{3}\right)\end{array}$ & $\begin{array}{c}\text { Total } \\
\text { Volume } \\
\left(10^{6} \mathrm{~m}^{3}\right)\end{array}$ & $\begin{array}{l}\text { Time to } \\
\text { Farthest } \\
\text { Point (s) }\end{array}$ & $\begin{array}{l}\text { Average } \\
\text { Velocity } \\
\left(\mathrm{m} \mathrm{s}^{-1}\right)\end{array}$ & $\begin{array}{c}\text { Ice and } \\
\text { Snow } \\
\text { (vol \%) }\end{array}$ \\
\hline Iliamna & 2300 & 1800 & 8800 & 0.2 & $\sim 6$ & & $12-20$ & $\sim 180$ & $\sim 48$ & $\sim 80^{\mathrm{c}}$ \\
\hline Aoraki/Mt. Cook & 3754 & 2720 & 6800 & 0.4 & $\sim 12$ & $48-68$ & $60-80$ & $\sim 120$ & $\sim 55$ & $10-80^{\mathrm{d}}$ \\
\hline
\end{tabular}

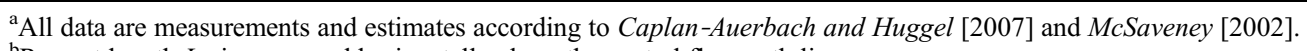

${ }^{\mathrm{b}}$ Runout length $L_{d}$ is measured horizontally along the central flow path line.

${ }^{c}$ Ice and snow content at the initiation of the avalanche and in the deposited material.

${ }^{\mathrm{d}}$ Range of ice and snow content from initiation of the avalanche to the deposited material. 
Table 2. Model Input Parameters for the Iliamna Red Glacier (Alaska) 2003 Avalanche and the Aoraki/Mt. Cook (New Zealand) 1991 Avalanche $^{\mathrm{a}}$

\begin{tabular}{lcc}
\hline \multicolumn{1}{c}{ Input Parameter } & Iliamna Red & Aoraki/Mt. Cook, \\
Glacier, 2003 & 1991 \\
\hline DTM (grid) & SRTM-1 30 m & NZ 25 m \\
Release density/avalanche & $1000 \mathrm{~kg} \mathrm{~m}^{-3}$ & $1100 \mathrm{~kg} \mathrm{~m}^{-3}$ \\
$\quad$ density $\left(\rho_{a}\right)$ & $6.2 \times 10^{6} \mathrm{~m}^{3}$ & $11.8 \times 10^{6} \mathrm{~m}^{3}$ \\
Release volume & $0.04-0.11$ & $0.06-0.15$ \\
Coulomb friction $(\mu)$ & $1550-6000 \mathrm{~m} \mathrm{~s}^{-2}$ & $900-7000 \mathrm{~m} \mathrm{~s}^{-2}$ \\
Turbulent friction $(\xi)$ & $10 \mathrm{~m}$ & $40 \mathrm{~m}^{-3}$ \\
Max. erosion depth $\left(h_{i}\right)$ & $600 \mathrm{~kg} \mathrm{~m}^{-3}$ & $600 \mathrm{~kg} \mathrm{~m}^{-3}$ \\
$\begin{array}{l}\text { Average density of } \\
\text { erodible layer }\left(\rho_{e}\right)\end{array}$ & $0.14 \mathrm{~m}^{-1}$ & $0.25 \mathrm{~m} \mathrm{~m}^{-1}$ \\
Erosion factor $\left(k_{2}\right)$ &
\end{tabular}

${ }^{\mathrm{a}}$ These parameters were constant for all calculations, except $\mu$ and $\xi$, which were systematically varied according to the indicated ranges (Figure 6).

\subsection{Model Application}

[35] The release area was reconstructed using airborne oblique photographs and the slope normal release thickness was set to $10.5 \mathrm{~m}$ with a resulting initial volume of $6.2 \times 10^{6} \mathrm{~m}^{3}$, similar to the volume estimated by Caplan-Auerbach and Huggel [2007] (Table 2). The avalanche density was set to an average of $1000 \mathrm{~kg} \mathrm{~m}^{-3}$ for a mix of predominantly snow, firn and ice, and a minor amount of rock and the density of the erodible layer to $600 \mathrm{~kg} \mathrm{~m}^{-3}$ for a mix of snow, firn, and ice. A few calibration runs were needed to find the erosion factor $k_{2}=0.14$ leading to the desired total eroded volume of approximately $10 \times 10^{6} \mathrm{~m}^{3}$, in the middle of the range of entrainment volumes estimated by Caplan-Auerbach and Huggel [2007].

[36] We used constant friction values for the entire flow path starting with $\mu=0.05$ and found $\xi=1850 \mathrm{~m} \mathrm{~s}^{-2}$ to match the observed runout distance. According to the parameter range of $0.03-0.10$ for $\mu$ suggested, e.g., by Sosio et al. [2008], we varied the $\mu$ value by 0.01 increments and determined $\xi$ values between 1550 and $4650 \mathrm{~m} \mathrm{~s}^{-2}$ to fit the observed runout distance (Figure 6).

\subsection{Model Results and Relation to Seismic Data}

[37] All four modeled examples show a good fit to the mapped avalanche outline while the geometrical fit of the calculations with smaller $\mu \xi$ values is marginally better than those with larger values (Figure 8). Topographically induced lateral deflection of the flow direction is enhanced with lower $\mu \xi$ combinations, resulting in a more distinct smaller flow lobe on the orographically right side and a better fit of the swashing on the left side (Figures 7 and 8).

[38] The maximum flow depths for the model runs are $50 \mathrm{~m}$ for the upper narrow section where the material converges, around $15 \mathrm{~m}$ for the central flow part, and rapidly reduce to $1-$ $3 \mathrm{~m}$ in the lower lateral sections (Figure 8). The modeled main debris deposits extend from the central avalanche part $4 \mathrm{~km}$ east of the initiation area to the lowest point of the avalanche and the thickness of the deposited material generally is $1-$ $10 \mathrm{~m}$. The available photographs suggest that the modeled deposition thickness lies within a reasonable range, but this comparison is of qualitative character.

[39] Erosion of snow, firn, ice and surface debris from Red Glacier concentrates along the central flow line of the avalanche where flow depth, flow velocities and hence the momentum are larger. There, modeled erosion depth has a maximum value of $8 \mathrm{~m}$ and is not larger than 1-2 $\mathrm{m}$ for the lateral zones, decreasing to zero in the lower section of the avalanche runout path. These values are plausible in relation to the event size, and traces of erosion and deposition on the images generally

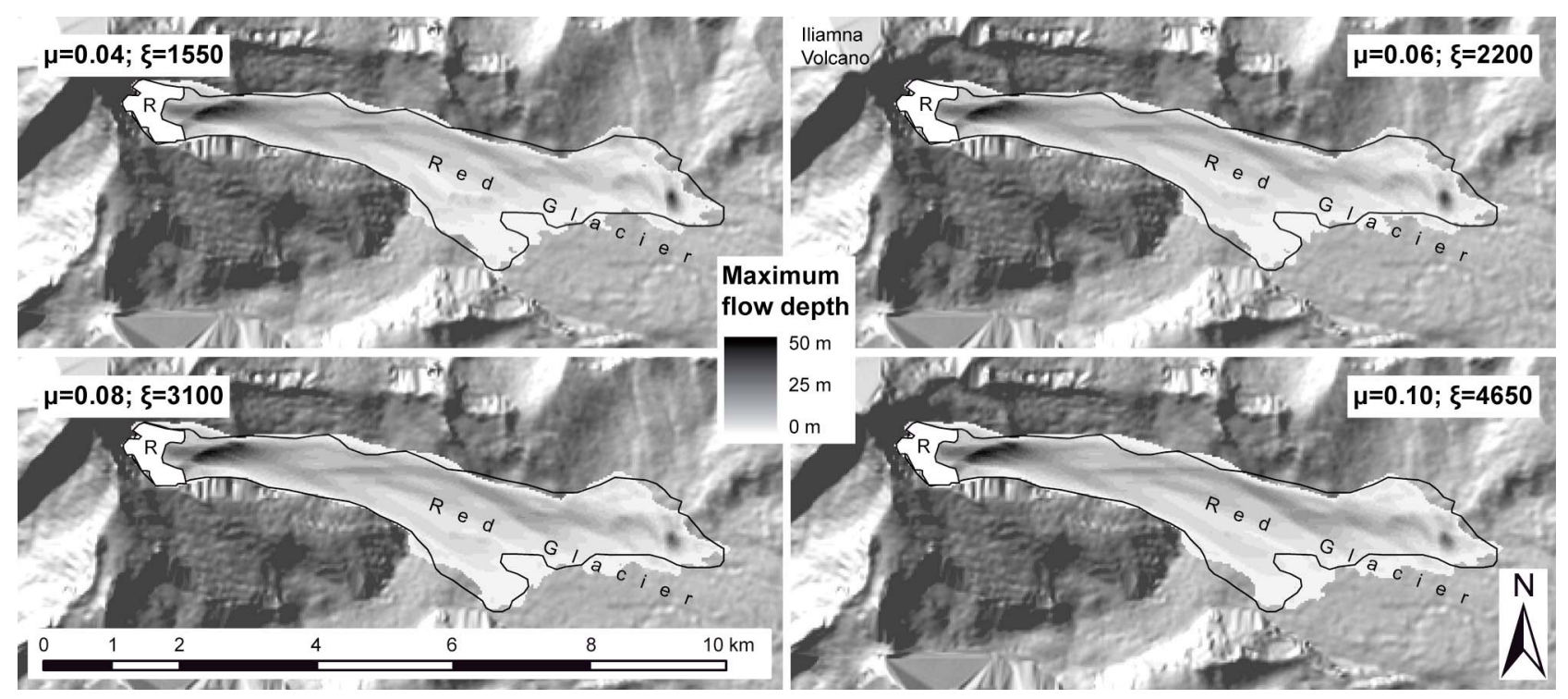

Figure 8. RAMMS output of maximum flow depth reached at each cell after $240 \mathrm{~s}$. The four individual simulations show that it is possible to model a given runout distance with different $\mu \xi$ combinations. Minor differences mainly concern the maximum reach of the orographically right smaller branch of the flow. Flow direction is from left to right, and the black line represents the mapped outline shape of the 25 July 2003 Red Glacier avalanche. The runs with smaller $\mu \xi$ combinations have a lateral extension that is closer to the outline geometry. The letter " $R$ " marks the release area. 
correspond well with the model predictions, however, detailed conclusions about the fit of modeled erosion are not possible. For a comparison of the dynamic characteristics of the real and simulated avalanches, we use the seismic data described in the following.

[40] We compared the original seismic signal and seismic envelope of the Iliamna Red Glacier 2003 avalanche to different model output parameters that all indicate a noticeable similarity with the seismic counterpart (Figure 9). The total
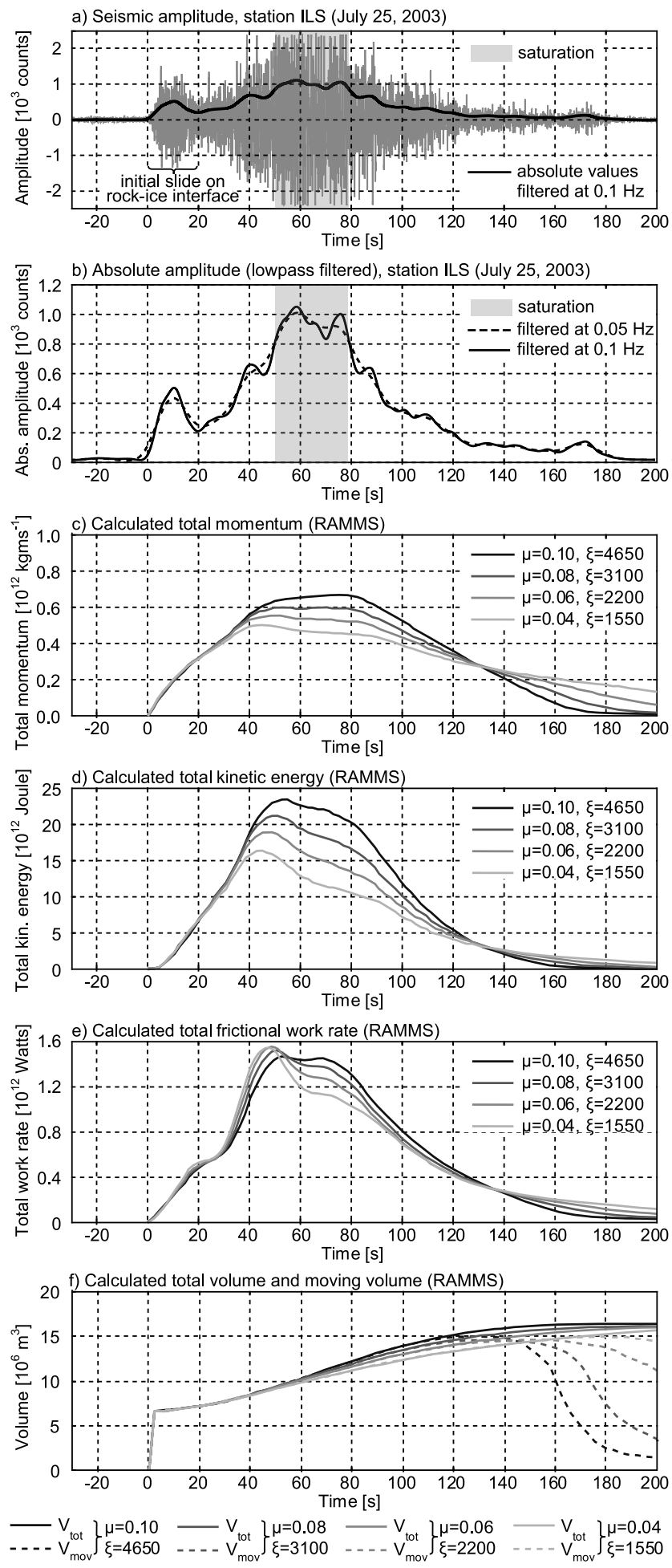

momentum, kinetic energy, and frictional work rate distributions over time depend on the combination of $\mu$ and $\xi$. For the $\mu-\xi$ combinations with larger values, the peaks are pronounced and during the run out of the avalanche, the curves decrease faster. The large amplitude of the signal between 0 and $15 \mathrm{~s}$ may be due to initial breakage of ice and rock combined with low attenuation because the movement takes place on bedrock where no energy absorbing snow and glacier ice is present. This effect is not unique to the 2003 avalanche and can be observed in the seismic data for all available recorded large avalanches on Red Glacier (1997, 2000, 2003 and 2008).

[41] We tested how well the normalized curves of the total momentum, kinetic energy and frictional work rate of the calculated avalanche correlate with the normalized curve of the absolute filtered amplitude of the seismogram. Correlation coefficients $\mathrm{R}^{2}$ were calculated between the total momentum, kinetic energy or frictional work rate of each model run (Table 3) and the seismic data filtered at $0.1 \mathrm{~Hz}$ $(10 \mathrm{~s})$ and $0.05 \mathrm{~Hz}(20 \mathrm{~s})$. The total momentum has the lowest correlation coefficients $\left(\mathrm{R}^{2}\right.$ between 0.692 and 0.811$)$. The correlation of the total kinetic energy is clearly higher $\left(\mathrm{R}^{2}\right.$ between 0.789 and 0.888 ). The best correlation is reached with the total frictional work rate $\left(\mathrm{R}^{2}\right.$ values between 0.782 and 0.904, Figure 10) which can be used for independent model calibration.

[42] In contrast to the planform outline geometry (Figure 8), the correlation analysis indicates a better agreement of the larger $\mu \xi$ combinations with the filtered seismic data. This conflict reveals the problem that looking at the geometry of a static avalanche calculation result (e.g., maximum flow depth or deposit) is possibly misleading from a dynamic and energetic point of view. Analysis of moving and total mass (Figure 9f) show that during the initial $140 \mathrm{~s}$, the release volume of $6.2 \times 10^{6} \mathrm{~m}^{3}$ erodes another $10-11 \times 10^{6} \mathrm{~m}^{3}$ and depending on the $\mu \xi$ combination, material starts to be deposited after 140-160 s. The larger the values of the $\mu \xi$ combination, the more abruptly the avalanche stops. Despite that, e.g., for $\mu=0.08$ and $\xi=3100 \mathrm{~m} \mathrm{~s}^{-2}$ at $t=180 \mathrm{~s} \mathrm{still} 50 \%$ of the mass is moving, yet the total momentum at this time is only $7 \%$ of the maximum total momentum. This can be explained by many "flowing" cells having either very small flow depths or small flow velocities, resulting in a small total kinetic energy $(<1 \%$ of the maximum kinetic energy at $t=$ $180 \mathrm{~s})$. In the case of lower $\mu \xi$ combinations, the modeled

Figure 9. Comparison of seismic records of the 25 July 2003 Red Glacier avalanche at Iliamna Volcano with RAMMS model calculations. (a) Seismogram for station ILS and filtered absolute values. The stronger signal at $t=$ $0-15 \mathrm{~s}$ is possibly referred to the initial slide on the rockice interface and a more efficient transmission of energy into the ground. The signal is saturated for $t=50-78 \mathrm{~s}$. (b) Absolute amplitude low-pass filtered at $0.1 \mathrm{~Hz}(10 \mathrm{~s})$ and $0.05 \mathrm{~Hz}$ (20 s). (c) Total momentum, (d) total kinetic energy, and (e) total frictional work rate for different $\mu \xi$ combinations calculated with RAMMS. (f) Evolution of the total volume of the avalanche due to erosion and the part which is still moving according to a defined threshold value. Most plots in Figures 9c, 9d, and 9e have a strong similarity to the filtered absolute amplitude in Figure 9b. 
Table 3. Correlation Analysis of RAMMS Modeling Results and Seismic Data From Figures 9 and $12^{\mathrm{a}}$

\begin{tabular}{|c|c|c|c|c|c|c|}
\hline & \multicolumn{2}{|c|}{ Total Momentum } & \multicolumn{2}{|c|}{ Total Kinetic Energy } & \multicolumn{2}{|c|}{ Total Frictional Work Rate } \\
\hline & $0.1 \mathrm{~Hz}(\mathrm{~m})$ & $0.05 \mathrm{~Hz}(\mathrm{~m})$ & $0.1 \mathrm{~Hz}$ & $0.05 \mathrm{~Hz}\left(10^{6} \mathrm{~m}^{3}\right)$ & $0.1 \mathrm{~Hz}\left(10^{6} \mathrm{~m}^{3}\right)$ & $0.05 \mathrm{~Hz}$ \\
\hline \multicolumn{7}{|l|}{ Iliamna runs } \\
\hline$\mu=0.04, \xi=1550$ & 0.692 & 0.699 & 0.789 & 0.808 & 0.782 & 0.805 \\
\hline$\mu=0.06, \xi=2200$ & 0.738 & 0.750 & 0.820 & 0.840 & 0.835 & 0.860 \\
\hline$\mu=0.08, \xi=3100$ & 0.765 & 0.780 & 0.844 & 0.866 & 0.868 & 0.893 \\
\hline$\mu=0.10, \xi=4650$ & 0.794 & 0.811 & 0.863 & 0.888 & 0.879 & $0.904^{\mathrm{b}}$ \\
\hline \multicolumn{7}{|l|}{ Aoraki/Mt. Cook runs } \\
\hline$\mu=0.09, \xi=1300$ & 0.357 & 0.384 & 0.545 & 0.574 & 0.651 & 0.675 \\
\hline$\mu=0.11, \xi=1750$ & 0.435 & 0.460 & 0.571 & 0.605 & 0.733 & 0.762 \\
\hline$\mu=0.13, \xi=2600$ & 0.495 & 0.524 & 0.592 & 0.631 & 0.799 & 0.833 \\
\hline$\mu=0.15, \xi=4000$ & 0.537 & 0.569 & 0.607 & 0.647 & 0.826 & $0.862^{\mathrm{b}}$ \\
\hline
\end{tabular}

${ }^{\mathrm{a}}$ Normalized total momentum, total kinetic energy, and total frictional work rate of modeled $\mu \xi$ combinations are compared to the normalized absolute count values of the seismogram filtered at $0.1 \mathrm{~Hz}(10 \mathrm{~s})$ and $0.05 \mathrm{~Hz}(20 \mathrm{~s})$. All values of the correlation analysis represent the correlation coefficient $\mathrm{R}^{2}$ of the modeled (RAMMS) and measured (seismometer) data between $t=0 \mathrm{~s}$ and $t=200 \mathrm{~s}$.

${ }^{\mathrm{b}}$ Correlation diagrams of these best fit values are shown in Figures 11 and 15.

avalanche reaches lower peak velocities but takes much more time to come to rest at a given runout distance.

[43] The simulated avalanches need between 170 and $186 \mathrm{~s}$ to reach the lowest point at a distance of $8800 \mathrm{~m}$ resulting in a horizontal average velocity of $47-52 \mathrm{~m} \mathrm{~s}^{-1}$ which is in good agreement with the mean velocity of $\sim 50 \mathrm{~m} \mathrm{~s}^{-1}$ reported by Caplan-Auerbach and Huggel [2007]. The simulations show

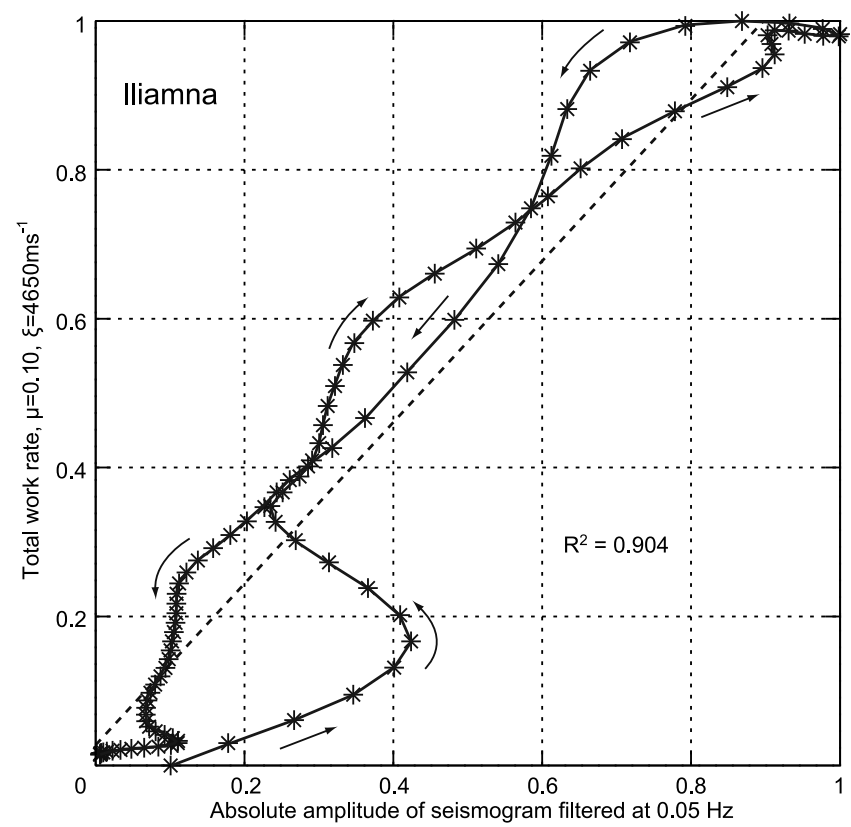

Figure 10. Plot of the best fit result from the correlation analysis between normalized seismic data and simulated avalanche parameters of Iliamna from Table 3 (sampled to $2 \mathrm{~s}$ steps between $t=0 \mathrm{~s}$ and $t=200 \mathrm{~s}$ ). Best fit results are achieved for comparisons of the seismograms filtered at $0.05 \mathrm{~Hz}(20 \mathrm{~s})$ with the total frictional work rate that was modeled with relatively high $\mu-\xi$ parameter values $(\mu=0.10$, $\xi=4650)$. Arrows indicate the time direction, and the start and end are situated at the lower left. The initial increase in seismic energy which was not observed in the model is recognizable by the stronger deviation from the solid linear regression line in the lower left corner. The linear regression is shown by the dashed line. peak velocities between 70 and $100 \mathrm{~m} \mathrm{~s}^{-1}$ for the central part of the avalanche and the kinetic energy at $t=180 \mathrm{~s}$ is clearly less than $15 \%$ of its maximum for all calculations.

\section{Aoraki/Mt. Cook 1991 Avalanche (NZ)}

\subsection{Setting and Characteristics of Event}

[44] Aoraki/Mt. Cook (3754 m asl) is the highest peak in New Zealand's Southern Alps, and situated at the Main Divide on the Main Divide fault, which is a parallel secondary fault of the $15 \mathrm{~km}$ northwestern Alpine fault (Figure 4). The closest settlement, Mount Cook village, is located $16 \mathrm{~km}$ to the south. The only infrastructure within several kilometers is Ball Shelter behind a lateral moraine of Tasman Glacier, and the Plateau Hut at $2200 \mathrm{~m}$ asl that serves as shelter for climbers (Figure 11).

[45] At 00:11 h local time on 14 December 1991, an avalanche of rock and ice occurred from High Peak, the uppermost part of Aoraki/Mt. Cook. The initial avalanche volume of approximately $12 \times 10^{6} \mathrm{~m}^{3}$ rapidly increased due to massive erosion of snow and ice, and passed within $300 \mathrm{~m}$ of the

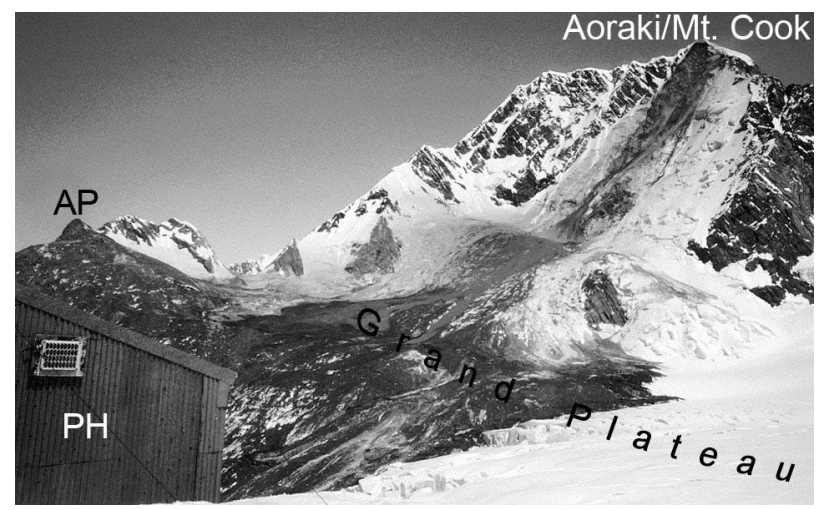

Figure 11. Upper and central part of the Aoraki/Mt. Cook avalanche of 14 December 1991. Detachment area is on the upper right. The flow path is well recognizable by the dark areas where massive erosion of ice and deposition of debris took place. The avalanche ran up for $200 \mathrm{~m}$ and overrode Anzac Peak (AP). Plateau Hut (PH) was missed by only $300 \mathrm{~m}$. Photo by I. Owens (16 December 1991). 


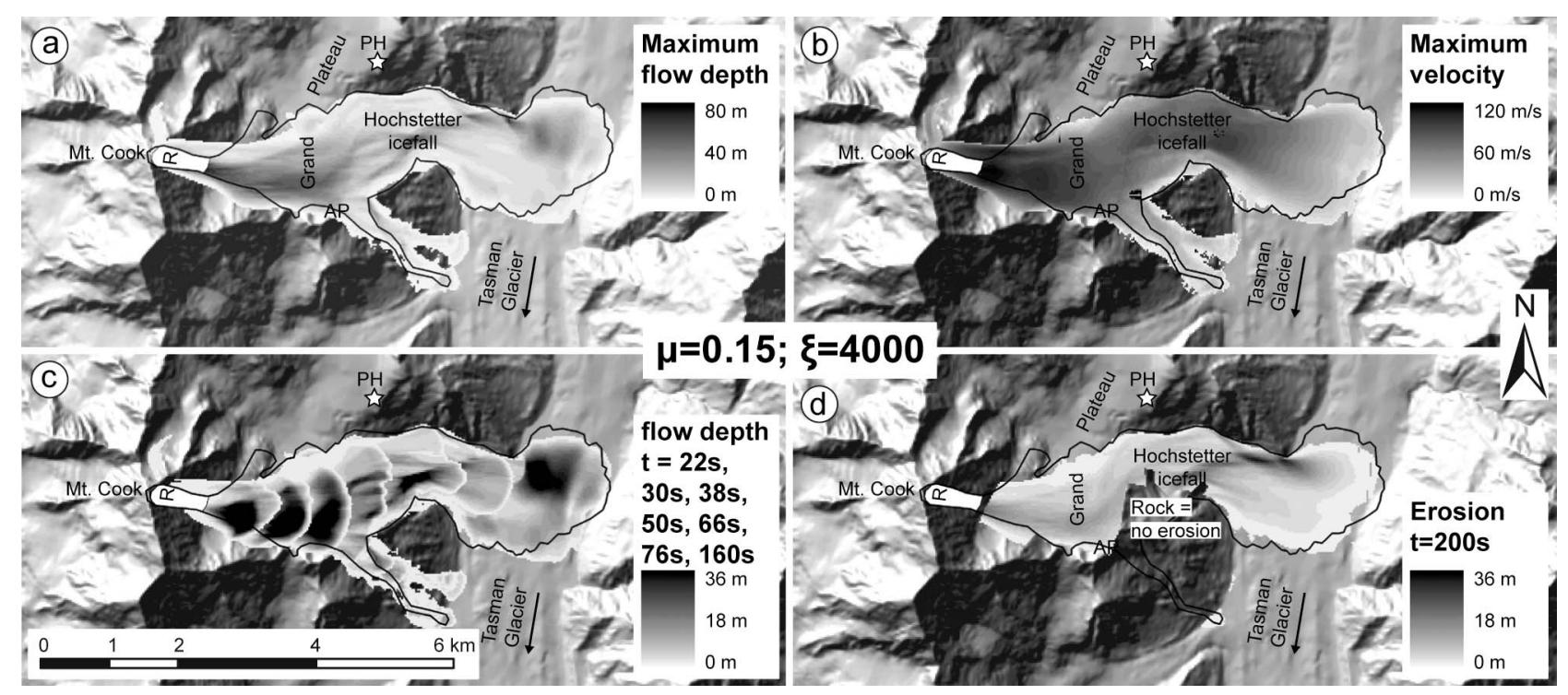

Figure 12. Various RAMMS results from a single simulation of the 14 December 1991 rock-ice avalanche from Aoraki/Mt. Cook (NZ) from the run with $\mu=0.15$ and $\xi=4000 \mathrm{~m} \mathrm{~s}^{-1}$ (highest correlation coefficient). (a) Maximum flow depths reach $80 \mathrm{~m}$ at an early stage of the avalanche but generally are not much higher than $36 \mathrm{~m}$. (b) Maximum velocities are close to $100 \mathrm{~m} \mathrm{~s}^{-1}$ over most of the avalanche track. (c) Overlapping flow depths for selected time steps (see Figure 13 for a more detailed view). (d) Momentum-dependent erosion was only allowed for the glacierized area. The Plateau Hut (PH) is marked with a white star. AP is Anzac Peak, and $\mathrm{R}$ is release area.

occupied Plateau Hut (Figures 4 and 11). After 2-3 min, a total volume of estimated $60-80 \times 10^{6} \mathrm{~m}^{3}$ [McSaveney, 2002] was deposited on Tasman Glacier as far as $6800 \mathrm{~m}$ in horizontal distance $L_{d}$, and $2720 \mathrm{~m}$ in height $H_{d}$ (resulting in an $H_{d} / L_{d}$ ratio of 0.4$)$. The ice content of the material increased from only $10 \mathrm{vol} \%$ in the initial mass to approximately $80 \mathrm{vol}$ $\%$ in the final deposit (Table 1). The avalanche path was mainly over firn and glacier ice above $2000 \mathrm{~m}$ asl, flowed through an ice fall with large seracs between 2000 and $1200 \mathrm{~m}$ asl, and then over the mostly debris-covered surface of the Tasman Glacier below $1200 \mathrm{~m}$ asl. Around $2300 \mathrm{~m}$ asl, a lateral branch of the avalanche ran $200 \mathrm{~m}$ up the orographic right side of the valley sidewall and overflowed a crest line to continue down to the boundary of Tasman Glacier [McSaveney, 2002].

\subsection{Model Application}

[46] The release area was defined as an elongated polygon with a slope normal average thickness of $42 \mathrm{~m}$. The total release volume was $11.8 \times 10^{6} \mathrm{~m}^{3}$, corresponding to the estimate made by McSaveney [2002]. Because the amount of rock is estimated to be slightly higher than at Iliamna, the density of the avalanche was set to an average of $1100 \mathrm{~kg} \mathrm{~m}^{-3}$ for a mix of snow, firn, ice and rock. This value also corresponds to the deposit density some days after the event reported by McSaveney [2002], excluding large rock boulders. We assume that the density during motion is lower, but including larger rock components the average density of $1100 \mathrm{~kg} \mathrm{~m}^{-3}$ is plausible. The average density of the erodible layers of snow, firn and ice was assumed to be similar to the one on Red Glacier in Alaska $\left(600 \mathrm{~kg} \mathrm{~m}^{-3}\right)$. An erosion factor $k_{2}=0.25$ was found to scale erosion of the glacier surface resulting in a deposition volume of $36 \times 10^{6} \mathrm{~m}^{3}$ that is smaller than but still within the precision of the estimate by McSaveney [2002] (M. J. McSaveney, personal communication, 2009). The difference of a factor two between reported and modeled deposition volumes is significant and definitively influences the momentum, kinetic energy, frictional work rate, and deposition thickness. However, model results with final volumes between 60 and $80 \times 10^{6} \mathrm{~m}^{3}$ have shown deposit thickness which did not match the pictures and reports from McSaveney [2002] while total work rate plots still maintained the basic shape with the three peaks. We therefore decided to assume a lower deposition volume. Applied friction values for the Aoraki/Mt. Cook avalanche ranged from 0.06 to 0.17 for $\mu$ and from 900 to $7000 \mathrm{~m} \mathrm{~s}^{-2}$ for $\xi$ (Figure 6).

\subsection{Model Results and Relation to Seismic Data}

[47] The best results concerning spatial extent of the avalanche were found for $\mu$ between 0.09 and 0.15 , and $\xi$ between 1300 and $4000 \mathrm{~m} \mathrm{~s}^{-2}$. Features like the southern smaller branch, runup to Anzac Peak, and a late reverse flow from Anzac Peak to the plateau with subsequent deposition are also observable in each simulation. Figure 12 gives an overview over 4 different RAMMS model outputs for a single simulation. Because the geometric results of various simulations with different $\mu \xi$ combinations fit well the mapped outlines from McSaveney [2002], we first focus on the dynamic characteristics of the modeled avalanche. The avalanche seismogram of the closest station Erewhon (EWZ) has 3 distinct pulses of energy (Figure 13a), which are also well visible in the filtered absolute amplitude of the seismogram (Figure 13b). The calculated momentum and kinetic energy plots in Figures 13c and 13d show only two distinct peaks in amplitude (peaks I and III). These two peaks correspond to the potential energy that is transformed into kinetic energy during 
the initial fall on the $55^{\circ}$ slope, up to the moment before most parts of the moving mass reach the relatively flat Grand Plateau (peak I), and again when it crosses the steep Hochstetter icefall (peak III). Because a higher kinetic energy for a given mass is induced by higher velocities, the frictional resistance forces do also increase ( $\xi$ term according to equation (4a) and (4b)) and lead to a higher frictional work rate (maxima I and III in Figure 13e and equation (7c)). The maxima I and III in Figures 13c, 13d, and 13e are separated by
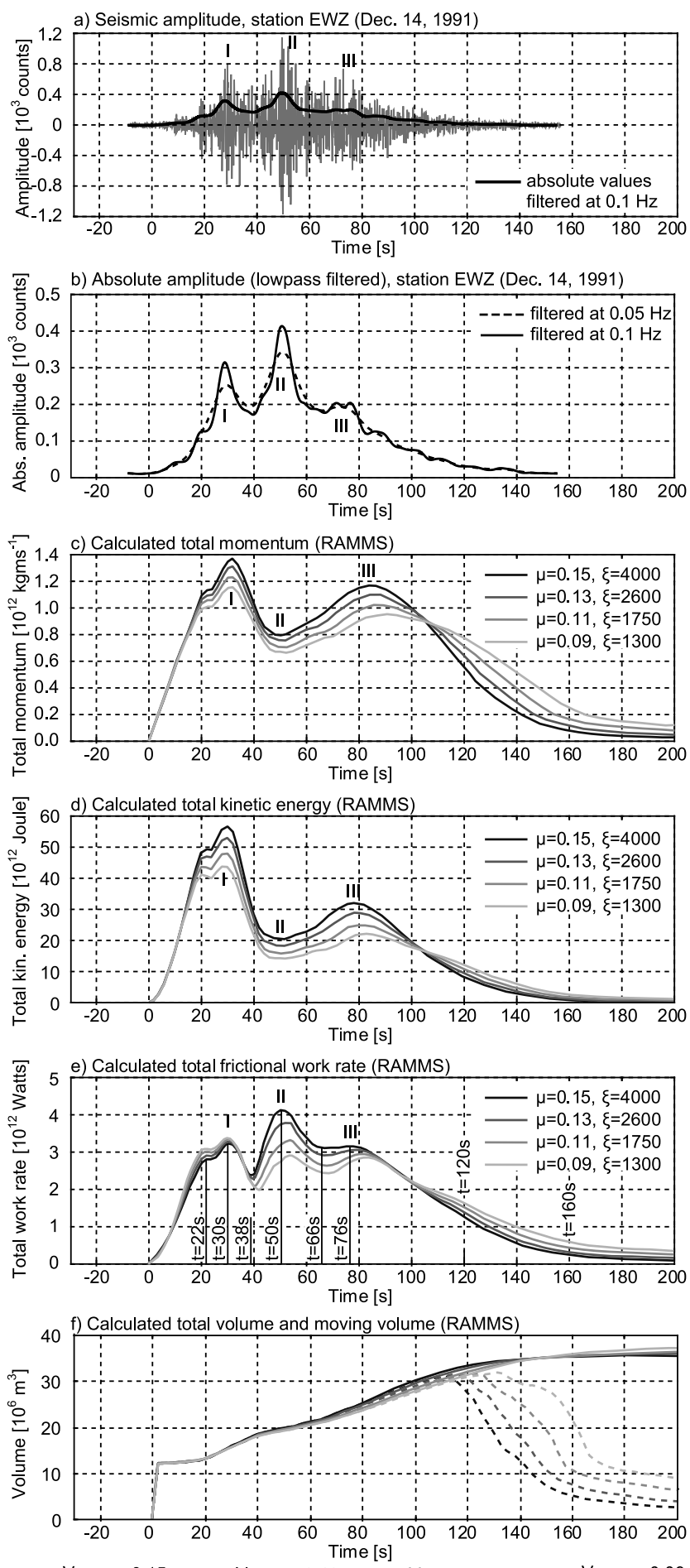

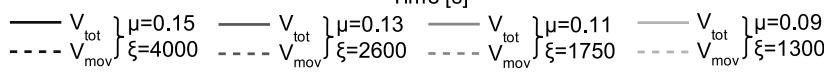

approximately $50 \mathrm{~s}$ which is similar for the peaks I and III in Figures 13a and 13b. This allowed fitting of the calculated curves to the seismic records.

[48] Peak number II is missing in the modeled total momentum and total kinetic energy plots because the avalanche loses momentum and kinetic energy on the flat part of the Grand Plateau. The total frictional work rate in Figure 13e, however, shows a third peak (peak II) between the others, exactly where the seismic signal has the highest amplitudes. This peak is related to an increased friction on a less inclined slope, leading to an enhanced frictional work rate and a strong loss of kinetic energy and momentum. The correlation analysis between the seismic data and all model results revealed low correlation coefficients $\mathrm{R}^{2}$ from 0.357 to 0.569 for the total momentum, and 0.545 to 0.647 for the total kinetic energy (Table 3 ). In contrast to this, the $\mathrm{R}^{2}$ values for the total frictional work rate are much better and range from 0.651 to 0.862 . As at Iliamna, correlation of seismic data with model runs having larger $\mu \xi$ combinations show better correlation coefficients (best fit with $\mu=0.15$ and $\xi=4000$ is shown in Figure 14).

[49] Modeled maximum flow depths, maximum velocities, instantaneous flow depths, and erosion in Figure 12 are those from the run with the best fit to the seismic data. Flow depths are between 10 and $20 \mathrm{~m}$ with some extreme values up to $60 \mathrm{~m}$. The modeled main deposit on Tasman Glacier has a maximum thickness of $36 \mathrm{~m}$, but most of it is thinner than $18 \mathrm{~m}$. The simulated avalanche reached the furthest point after $120 \mathrm{~s}$ (see also Figure $15 \mathrm{~g}$ ). For a horizontal runout distance of $6800 \mathrm{~m}$, this leads to a horizontal average velocity component of $\sim 56 \mathrm{~m} \mathrm{~s}^{-1}$ while the maximum slope-parallel velocities were between 80 and $100 \mathrm{~m} \mathrm{~s}^{-1}$ for extended sections. Erosion of snow, firn, ice, and debris cover on the glacier surfaces, for which erosion was allowed, reach 5-10 m in the steeper parts, where the avalanche is moving fast, and show a maximum of $\sim 30 \mathrm{~m}$ on the orographically left side below Hochstetter Icefall, where the debris is piled up on the steep sidewall. The concentration of erosion on this site is due to the momentum-dependent erosion, that means where the largest momentum appears, the strongest erosion occurs. These results are in general agreement with the findings and photos of McSaveney [2002].

Figure 13. Comparison of seismic records of the 14 December 1991 Aoraki/Mt. Cook avalanche (NZ) with RAMMS model calculations. (a) Seismogram for station EWZ and filtered absolute values. The initiation of the avalanche shows low signal amplitude and cannot be clearly seen, probably due to almost free fall conditions. (b) Absolute amplitude low-pass filtered at $0.1 \mathrm{~Hz}(10 \mathrm{~s})$ and $0.05 \mathrm{~Hz}(20 \mathrm{~s})$. (c) Total momentum, (d) total kinetic energy, and (e) total frictional work rate for different $\mu \xi$ combinations calculated with RAMMS. (f) Evolution of the total volume of the avalanche due to erosion and the part which is still moving according to a defined threshold value. Note the similarity of absolute amplitude filtered at $0.1 \mathrm{~Hz}$ (Figure 13b) and calculated total frictional work rate for $\mu=0.15$ and $\xi=4000 \mathrm{~m} \mathrm{~s}^{-2}$ (Figure 13e). Time steps for local maxima and minima of this run are highlighted in Figure 13e, and specific avalanche flow depths for each corresponding time step are shown in Figure 12. 


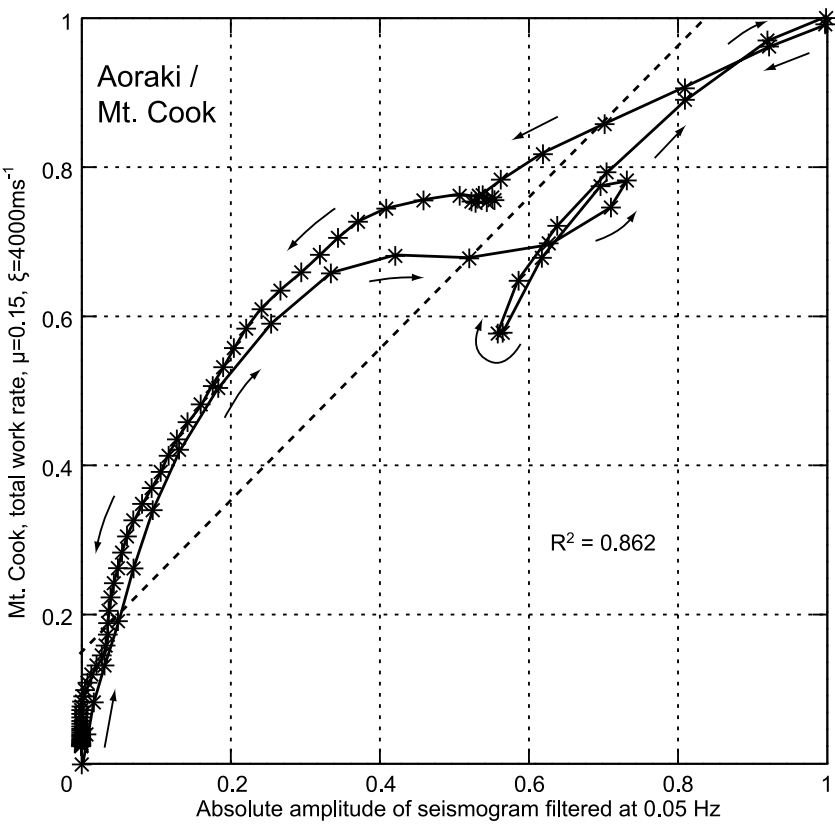

Figure 14. Plot of the best fit result of the correlation analysis between normalized seismic data and simulated avalanche parameters of Aoraki/Mt. Cook from Table 3 (sampled to $2 \mathrm{~s}$ steps between $t=0 \mathrm{~s}$ and $t=200 \mathrm{~s}$ ). Best fit results are achieved for comparisons of the seismograms filtered at $0.05 \mathrm{~Hz}(20 \mathrm{~s})$ with the total frictional work rate that was modeled with relatively high $\mu-\xi$ parameter values $(\mu=$ $0.15, \xi=4000)$. Arrows indicate the time direction, and the start and end are situated at the lower left. The linear regression is shown by the dashed line.

[50] Figure 15 shows a more detailed RAMMS output time series of the instantaneous flow depth taken from Figure 12c. Each plot relates to the time when the avalanche reaches a local minimum or maximum in the total frictional work rate curve from Figure 13e. We can see that the avalanche's frictional work rate is at a local maximum when the kinetic energy is very high (after crossing a steep part, e.g., at $t=22 \mathrm{~s}$, $30 \mathrm{~s}$ and $76 \mathrm{~s}$ ), as well as when the avalanche is running fast over a less inclined surface and frictional resistance forces are increased (after crossing a flat part, e.g., at $t=50 \mathrm{~s}$ ). The longer the avalanche is running, the more the mass gets distributed along the flow path and the described effects become less clear. This might be the reason why the second major step in topography at Hochstetter Icefall appears less pronounced in the seismogram and the calculated work rate plots, than the initial fall when the mass is still very compact.

\section{Discussion}

\subsection{Performance of the Numerical Model}

[51] Commonly, avalanche model parameters are evaluated by fitting to the observed runout distance. However, a mass movement model should not only reproduce correct runout distances, but simultaneously fit geometric, energetic, and dynamic observations. Although the model is not able to exactly match every characteristic of the avalanche, the total level of fit suggests that the model adequately represents the real process.
[52] Uncertainties of the detachment volumes often are within a range of $10-20 \%$ or more, but uncertainties about erosion and the final volume are much larger. Within the analysis strategy to fit the runout distance, the uncertainty in erosion affects the frictional parameters. In turn, erosion and deposition depths/volumes are affected by the friction parameters. Independent data are needed to validate the model quantitatively. The simplest independent variable we used was the lateral expansion of the avalanche (entire outline geometry). The model fails when the lateral deposition of the avalanche is significantly different from the mapped real extent. Another variable could be the deposition thickness including the final volume, but unfortunately, a lack of data required us to verify erosion and deposition qualitatively according to the available photographs and field reports. We used the seismograms as another independent semiquantitative source to validate the energetic and dynamic fit of the model results. We call seismograms semiquantitative validation sources because site and path effects are difficult to quantify and may have a significant effect on the appearance of the seismic signal at large distances [Deparis et al., 2008].

[53] Some differences between modeled and observed avalanches can be explained by a number of simplifications that were made, such as constant average friction parameters which are too large for an avalanche running over pure ice but also too small for a debris covered glacier surface. Because the model uses constant flow density, the avalanche density was adjusted for the deposits while real flow densities might have varied during downstream movement, generally being lower than defined within the input variables but being higher for the unbroken release mass. However, flow density is only used for flow pressure calculations and does not affect the propagation of the flow. Likewise, the average erosion density is too high if erosion is only superficial, but too low if erosion is deep or includes denser rock fragments. The application of momentum-dependent erosion is a further approximation of the real erosion process, and testing other erosion models is suggested.

[54] The accuracy and resolution of the DTM is crucial for all model calculations and it should stand in a reasonable relation to the avalanche size. While SRTM-1 is a sufficient resolution for an avalanche of several million cubic meters flowing many kilometers, it is too coarse for much smaller events [Christen et al., 2010a; Schneider et al., 2008]. However, the problem of DTM quality in glacial environments is often more due to topographic changes between the DTM acquisition time and the avalanche event. Therefore, the availability of preevent and postevent DTMs representing the topography shortly before and after the event is an important factor for the success of retrospective modeling. It further helps to calculate the erosion and deposition, and hence the volume of the avalanche, to better fit the geometric criteria.

[55] We generally used higher $\mu \xi$ combinations than, e.g., Hungr and Evans [1996] used for modeling the 27 March 1964 avalanche on Sherman Glacier $\left(\mu=0.03, \xi=1000 \mathrm{~m} \mathrm{~s}^{-1}\right)$, Sosio et al. [2008] based on an analysis of the 18 September, 2004 Thurwieser rock avalanche on Zebrù Glacier for rock-ice avalanches in general $\left(\mu=0.03-0.1, \xi=1000 \mathrm{~m} \mathrm{~s}^{-1}\right)$, or Lipovsky et al. [2008] for the 24 July, $2007 \mathrm{Mt}$. Steele rock-ice avalanche $\left(\mu=0.052, \xi=1525 \mathrm{~m} \mathrm{~s}^{-1}\right)$. A reason is that modeled process durations to reach the full runout distance might be too high in certain cases where low $\mu \xi$ combinations 


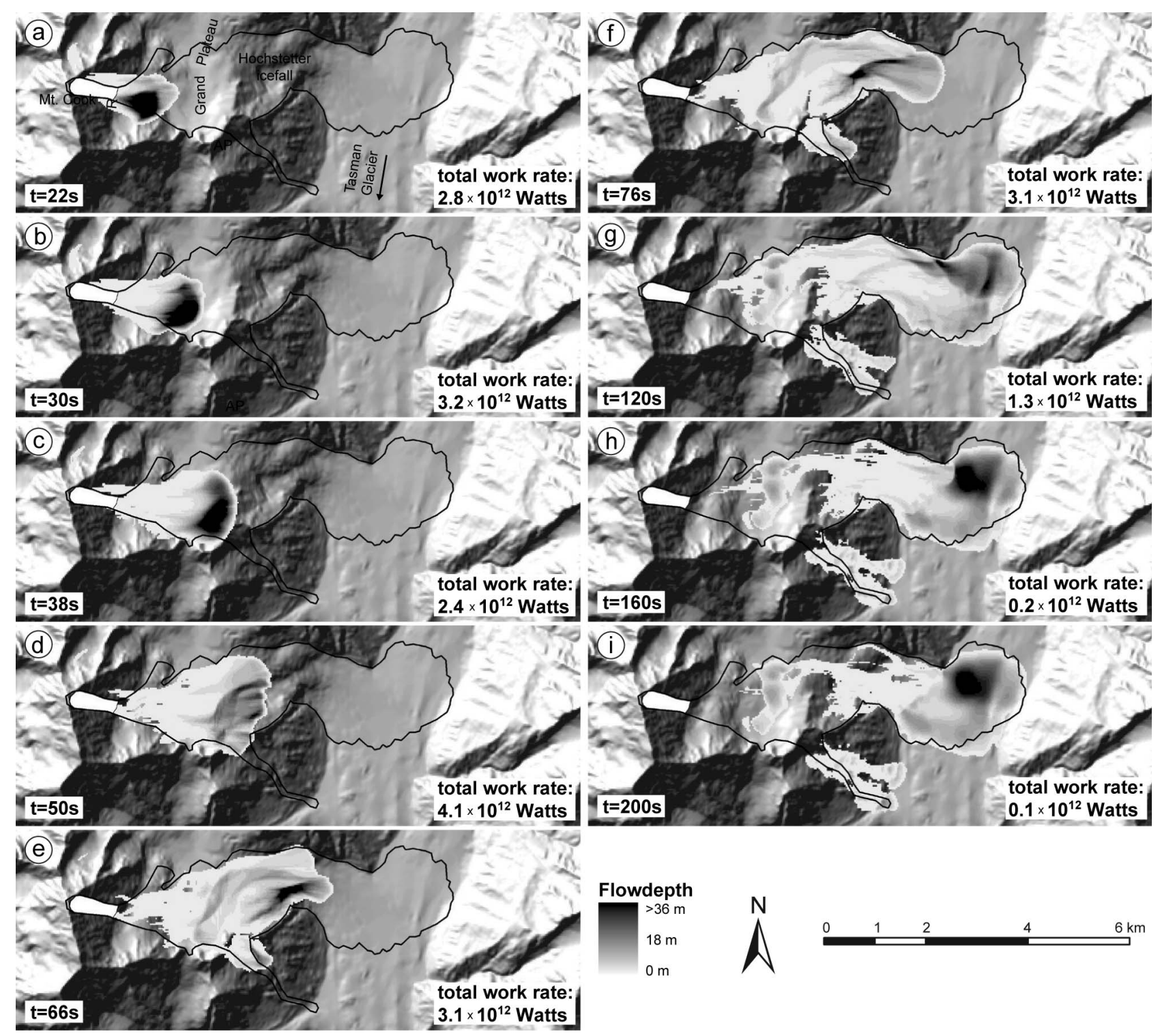

Figure 15. (a-i) RAMMS output time series of the instantaneous flow depth of the 14 December 1991 Aoraki/Mt. Cook avalanche (NZ) with friction parameters $\mu=0.15$ and $\xi=4000 \mathrm{~ms}^{-1}$. Selected time steps correspond to the local maxima and minima of the total frictional work rate indicated in Figure 14e. Total frictional work rate for all time steps is given in Watts $\left(\mathrm{J} \mathrm{s}^{-1}\right)$. Figure $15 \mathrm{i}$ can also be seen as the deposition height because the total kinetic energy is lower than $1 \%$ of the maximum kinetic energy. The release area is the white polygon on the left side of the images.

were used. Very low Coulomb friction coefficients $\mu$ below 0.05 still allow a slow, largely velocity-independent sliding on a slope of only $3^{\circ}$ far distant from the source $(\arctan \mu=$ $2.86^{\circ}$ ). Even on ice this is a very low value for a dry granular mass; however, it is realistic if the mass movement transforms to a debris flow and enough water has been incorporated (or melted snow/ice due to frictional heating). This has been observed, e.g., at the rock-ice avalanches from Huascarán, Peru [Evans et al., 2009a], or at Kolka-Karmadon, Russian Caucasus [Evans et al., 2009b; Huggel et al., 2005]. As soon as the avalanche reaches a slope with inclinations smaller than arctan $\mu$, frictional forces are higher than gravitational acceleration and the avalanche starts decelerating. The only thing defining that an avalanche can reach a more distant point is the avalanche momentum before deceleration starts. Frictional processes have to dissipate all the kinetic energy available from that point on. If we increase the turbulent friction coefficients $\xi$, the avalanche will accelerate faster in the early phase of failure in steep terrain, where high velocities are reached anyway. High $\xi$ values reduce the turbulent friction term significantly during higher velocities, leading to less frictional resistance and higher velocities again (equations (4a) and (4b) and Figures 9 and 13). At low velocities, this term anyway approximates zero and $\xi$ is no longer relevant. Higher $\mu \xi$ combinations therefore lead to higher peak velocities, faster stopping mechanisms, and hence to shorter process 
durations which are supported by the seismograms used in this study. Abrupt stopping was also observed from rock avalanches triggered by nuclear explosions at the Russian Novaya Zemlya test site [Adushkin, 2006].

\subsection{Contribution of Seismic Data}

[56] Seismic recordings often are the only evidence for the energetic and dynamic evolution of large avalanches. In the modeled total momentum, kinetic energy, and frictional work rate we found three parameters which should generally correlate with the seismograms. The calculated total frictional work rate shows the best correlation values $\left(\mathrm{R}^{2}\right)$ and is hence recommended for qualitative comparison with seismic data from nearby stations to evaluate the model results and to get a better insight into avalanche dynamics.

[57] The total frictional work rate calculated by the model depends on the frictional rheology but is largely controlled by the topography over which the avalanche is flowing. Topographic features such as major flat and steep parts should be evident in both the modeled frictional work rate and in the seismograms [see also Favreau et al., 2009]. If three-component seismic data are available within a short distance from the source, calculations of the total received energy might be more representative than only horizontally polarized signals. However, many stations still record only vertical components, and Suriñach et al. [2001] have shown that the absolute amplitudes in three-component signals can be different, while seismic energy and frequency content are similarly distributed. Because our analysis is based only on the shape of the seismograms (amplitude envelopes, Figures 3 and 5) and not on the magnitudes, the vertical component should sufficiently well represent the information needed for comparison with modeling results.

[58] We expect differences in the amplitude of horizontal and vertical seismic waves depending on the azimuth direction of the seismic station in relation to the avalanche site and direction of movement [Suriñach et al., 2001] (see stations EWZ, LMZ and BWZ at Aoraki/Mt. Cook). Acceleration or deceleration of a mass, e.g., in west-east direction might cause a stronger WE signal than the NS component. The $\mathrm{Z}$ component in turn, will better reflect vertical impacts of mass, such as after a near free fall on a topographic step like at Aoraki/Mt. Cook or the vertical impact component of granular random kinetic energy in the basal shear layer [Buser and Bartelt, 2009]. Thus, the seismic Z component could also be a measure for random kinetic energy which was proposed by Buser and Bartelt [2009]. According to their work, the random kinetic energy is a function of the frictional work rate done by the avalanche. The good correlation between the vertical seismic data and the total frictional work rate therefore supports a possible relation between the avalanche's random kinetic energy, its frictional work rate, and the seismic data. We expect that the frictional work rate is better represented by short-period stations (which have to be close) than by long-period stations (which can also be remote), because frictional interaction and random kinetic energy should be largely of high frequency. Low-frequency signals are more related to loading and unloading of the source area, the path, and the deposition area, that cannot be simulated directly with the used model. A fast degrading short-period signal can further be an advantage in terms of reducing disturbance by other seismic sources such as the beat of the sea which can strongly affect long-period signals [McSaveney, 2002].

[59] A landslide or avalanche event is usually captured by more than one seismic station, but path effects are likely to have a greater effect on more distal seismograms. Deparis et al. [2008] used a seismic network of up to 21 stations in the French Alps to analyze seismograms of rockfall avalanches with volumes between $2 \times 10^{3}$ and $1.75 \times 10^{6} \mathrm{~m}^{3}$. The stations were within distances of $10-250 \mathrm{~km}$, and due to the rapid degradation of the signal with distance they concentrated on the closest station for each event (usually between 10 and $25 \mathrm{~km}$ ). Weichert et al. [1994] worked with stations between 60 and $250 \mathrm{~km}$ from the 1990 Brenda mine collapse and 1965 Hope rockslides in British Columbia, Canada, to differentiate between seismic signals from earthquakes and landslides. They interpreted the short-period signal as characteristic of the rockslide and stated that this signal was only recorded to a few hundred kilometers. In contrast to this, Brodsky et al. [2003] used the far reaching long-period signal of large landslides at epicentral distances of up to $7000 \mathrm{~km}$ to estimate basal friction. In the case of the Iliamna avalanche, the closest stations within $8 \mathrm{~km}$ were all saturated. Because all sensors were short period at the time of the avalanche and due to the reasons above, we suggest using the nearest least saturated signal. Station ILS at $8 \mathrm{~km}$ distance was saturated for $\sim 20 \mathrm{~s}$ while the signal at the next station RSO $(51 \mathrm{~km}$ distance) had a much lower signal-to-noise ratio. The signal was also compared to other stations with similar distances and azimuth ranges and high consistence was found (Figure 3b).

[60] Similarities and deviations between the theoretical values (total frictional work rate calculation) and the measurements (seismogram) can enhance the general understanding of the energetic and dynamic characteristics of a mass movement, such as major changes in the topographic geometry of the runout path, frictional conditions, and centrifugal effects can be identified in both the calculation and the seismogram. An evaluation of the model results by finding the best fitting frictional work rate compared to the seismogram, either qualitatively or quantitatively by correlation, helps to determine the exact timing of the failure (in detail by shifting the time axis of one data set to best fit the other data set) and to better constrain the range of the input friction parameters. Additionally, identification of single, multiple and progressive failure is possible. If more than one individual failure occurs (e.g., within 20-200 s), we are currently unable to simulate this process with the model but can recognize this in the much longer seismic signal compared to the simulated process duration of a single failure. The seismic waves of the individual failures will be superimposed and mixed, making the seismogram useless for comparison with the frictional work rate plots.

[61] A delicate point when using seismic signals is that the efficiency of seismic energy conversion seems to be very low. Berrocal et al. [1978] have shown that $1 \%$ of the potential energy of the 1974 Mantaro slide in Peru was converted into kinetic energy, of which only $0.01 \%$ was again converted into seismic energy. This results in an efficiency of seismic energy conversion of only $10^{-6}$ for this case [see also Weichert et al., 1994]. For the presented case studies we do expect a somewhat higher efficiency in the conversion of potential to kinetic energy due to the low-friction surface on glacier ice. How- 
ever, the efficiency in converting kinetic energy into seismic energy might be lower due to restraining effects of the underlying glacier. Hence, small changes in the efficiency of converting potential to kinetic energy as well as in converting kinetic into seismic energy during an avalanche event can have a strong influence on the resulting signal amplitudes. With respect to this, the good correlation between the seismic signals and the modeled total frictional work rate is remarkable and a predominantly constant seismic efficiency can be assumed for the two presented case studies. A comparison of any other modeled avalanche data with seismograms can only be successful if the seismic efficiency is largely constant.

[62] We evaluated several possibilities of combining seismic data and numerical model calculations, first on the very simple topography at Iliamna volcano in Alaska as a kind of "natural laboratory" and then in a much more spatially variable terrain such as at Aoraki/Mt. Cook (NZ). Despite the above mentioned simplifications and some uncertainties, the combination of seismic data with simulation results of the RAMMS model are promising and should be tested with other models and frictional rheologies at different study sites and for a broad variety of avalanche volumes and types. Particularly for large avalanches, the problem of sparse data is crucial and some characteristics like flow velocities may be well reconstructed with seismic data and any dynamic model capable of calculating momentum, kinetic energy, and frictional work rate.

\section{Conclusions}

[63] This work illustrates how seismic recordings can be used as independent data to better constrain the range of appropriate input parameters of a numerical avalanche model. Higher reliability of the model results in turn can lead to better insights into rock-ice avalanche dynamics. The main findings are as follows.

[64] 1. Model optimization and evaluation (e.g., determination of appropriate friction parameters) should be done systematically using geometric, energetic, and dynamic aspects of the avalanche.

[65] 2. For very large avalanches, seismic recordings are often the only data available for characterizing dynamic aspects. Such data may be obtained even for remote areas and are largely independent of weather conditions.

[66] 3. Dynamic model results should be compared to the seismic pattern of an avalanche event so that the model results are dynamically consistent with the seismic data over the entire displacement process and not only in the final resting state (deposition geometry and total duration).

[67] 4. Among different dynamic parameters, the total frictional work rate was found to best correlate with the seismic signal. The frictional work rate describes the rate of energy loss by the avalanche due to friction, and we suggest that the energy captured by the seismograph represents a small but proportional fraction of this energy loss.

[68] 5. Differences between the seismic data and the modeled total frictional work rate indicate source site, path, and recorder site effects, or departures of the model from reality (e.g., no single failure, wrong frictional properties). Such findings can in turn be used to assess the model quality or to optimize the choice of frictional parameters and other variables used for modeling.

\section{Notation}

$A$ cell area, $\mathrm{m}^{2}$.

$g$ gravitational acceleration, $\mathrm{m} \mathrm{s}^{-2}$.

$g_{x}$ gravitational acceleration component in $x$ direction, $\mathrm{m} \mathrm{s}^{-2}$.

$g_{y}$ gravitational acceleration component in $y$ direction, $\mathrm{m} \mathrm{s}^{-2}$.

$g_{z}$ gravitational acceleration component in $z$ direction, $\mathrm{m} \mathrm{s}^{-2}$.

$h$ entrainment depth, m.

$H$ flow depth, m.

$H_{d}$ vertical distance, $\mathrm{m}$.

$H_{i}$ flow depth at cell $i, \mathrm{~m}$.

$i$ cell number, dimensionless.

$k_{\text {tot }}$ total kinetic energy, J.

$k_{1}$ erosion factor for velocity-dependent entrainment, dimensionless.

$k_{2}$ erosion factor for momentum-dependent entrainment, $\mathrm{m}^{-1}$.

$L_{d}$ horizontal distance, $\mathrm{m}$.

$m$ mass, $\mathrm{kg}$.

$n$ number of cells affected by the avalanche, dimensionless.

$p$ momentum, $\mathrm{kg} \mathrm{ms}^{-1}$.

$p_{\text {tot }}$ total momentum, $\mathrm{kg} \mathrm{ms}^{-1}$.

$\dot{Q}$ entrainment rate, $\mathrm{m} \mathrm{s}^{-1}$.

$\dot{Q}_{p}$ momentum-dependent entrainment rate, $\mathrm{m} \mathrm{s}^{-1}$.

$\hat{Q}_{U}$ velocity-dependent entrainment rate, $\mathrm{m} \mathrm{s}^{-1}$.

$S_{f x}$ frictional deceleration force in x direction, $\mathrm{m}^{2} \mathrm{~s}^{-2}$.

$S_{f y}$ frictional deceleration force in y direction, $\mathrm{m}^{2} \mathrm{~s}^{-2}$.

$S_{g x}$ gravitational acceleration force in $\mathrm{x}$ direction, $\mathrm{m}^{2} \mathrm{~s}^{-2}$.

$S_{g y}$ gravitational acceleration force in y direction, $\mathrm{m}^{2} \mathrm{~s}^{-2}$.

$t$ time, s.

$U$ velocity, $\mathrm{m} \mathrm{s}^{-1}$.

$U_{i}$ velocity at cell $i, \mathrm{~m} \mathrm{~s}^{-1}$.

$U_{x}$ depth averaged avalanche velocity in $\mathrm{x}$ direction, $\mathrm{m} \mathrm{s}^{-1}$.

$U_{y}$ depth averaged avalanche velocity in y direction, $\mathrm{m} \mathrm{s}^{-1}$.

$V_{t o t}$ total volume of avalanche, $\mathrm{m}^{3}$.

$V_{\text {mov }}$ moving volume of avalanche, $\mathrm{m}^{3}$.

$W_{\text {tot }}$ total frictional work rate, $\mathrm{J} \mathrm{s}^{-1}$.

$x$ local surface-parallel direction, $\mathrm{m}$.

$y$ local surface-parallel direction, $\mathrm{m}$.

$z$ local surface-normal direction, $\mathrm{m}$.

$\alpha$ slope, deg.

$\mu$ Coulomb friction, dimensionless.

$\xi$ turbulent friction, $\mathrm{m} \mathrm{s}^{-2}$.

$\rho_{a}$ density of avalanche, $\mathrm{kg} \mathrm{m}^{-3}$.

$\rho_{e}$ density of erodible layer, $\mathrm{kg} \mathrm{m}^{-3}$.

[69] Acknowledgments. This work was supported by the Swiss National Foundation grant NF 200021-121823/1 (Rock-ice avalanches: A systematic investigation of the influence of ice). We are deeply grateful to Mauri J. McSaveney's essential conceptual contributions and thorough review. The reviews of Stephen G. Evans, two other unknown reviewers, and the associate editor, as well as from the editor Michael Church, helped to improve the manuscript significantly. We further thank Julia Kowalski, Simon Allen, Wilfried Haeberli, and Stefanie Gubler for their support.

\section{References}

Adushkin, V. V. (2006), Mobility of rock avalanches triggered by underground nuclear explosions, in Landslides From Massive Rock Slope Failures, edited by S. G. Evans et al., pp. 267-284, doi:10.1007/978-1-40204037-5 15, Springer, Netherlands.

Aki, K., and B. Chouet (1975), Origin of coda waves: Source, attenuation and scattering effects, J. Geophys. Res., 80(23), 3322-3342, doi:10.1029/ JB080i023p03322.

Alean, J. (1984), Untersuchungen über Entstehungsbedingungen und Reichweiten von Eislawinen, PhD thesis, 217 pp., Swiss Fed. Inst. of Technol., VAW/ETH Zurich, Zurich. 
Allen, S., D. Schneider, and I. F. Owens (2009), First approaches towards modelling glacial hazards in the Mount Cook region of New Zealand's Southern Alps, Nat. Hazard. Earth Syst. Sci., 9(2), 481-499, doi:10.5194/nhess-9-481-2009.

Armento, M. C., R. Genevois, and P. R. Tecca (2008), Comparison of numerical models of two debris flows in the Cortina d'Ampezzo area Dolomites, Italy, Landslides, 5, 143-150, doi:10.1007/s10346-007-0111-2.

Bartelt, P., and O. Buser (2009), Frictional relaxation in avalanches, Ann. Glaciol., 51(54), 1-5.

Bartelt, P., B. Salm, and U. Gruber (1999), Calculating dense-snow avalanche runout using a Voellmy-fluid model with active/passive longitudinal straining, J. Glaciol., 45(150), 242-254.

Bartelt, P., O. Buser, and K. Platzer (2007), Starving avalanches: Frictional mechanisms at the tails of finite-sized mass movements, Geophys. Res. Lett., 34, L20407, doi:10.1029/2007GL031352.

Berrocal, J., A. F. Espinosa, and J. Galdos (1978), Seismological and geological aspects of the Mantaro landslide in Peru, Nature, 275, 533-536, doi: $10.1038 / 275533 \mathrm{a} 0$.

Bottino, G., M. Chiarle, A. Joly, and G. Mortara (2002), Modelling rock avalanches and their relation to permafrost degradation in glacial environments, Permafrost Periglacial Processes, 13(4), 283-288, doi:10.1002/ppp.432.

Bouchut, F., E. D. Fernández-Nieto, A. Mangeney, and P.-Y. Lagrée (2008), On new erosion models of Savage-Hutter type for avalanches, Acta Mech., 199(1-4), 181-208, doi:10.1007/s00707-007-0534-9.

Brodsky, E. E., E. Gordeev, and H. Kanamori (2003), Landslide basal friction as measured by seismic waves, Geophys. Res. Lett., 30(24), 2236 , doi:10.1029/2003GL018485.

Buser, O., and P. Bartelt (2009), Production and decay of random kinetic energy in granular snow avalanches, J. Glaciol., 55(189), 3-12, doi:10.3189/002214309788608859.

Buser, O., and H. Frutiger (1980), Observed maximum run-out distance of snow avalanches and the determination of the friction coefficients $\mu$ and $\xi$, J. Glaciol., 26(94), 121-130.

Caplan-Auerbach, J., and C. Huggel (2007), Precursory seismicity associated with frequent, large ice avalanches on Iliamna volcano, Alaska, USA, J. Glaciol., 53(180), 128-140, doi:10.3189/172756507781833866.

Caplan-Auerbach, J., S. Prejean, and J. A. Power (2004), Seismic recordings of ice and debris avalanches of Iliamna Volcano, Alaska, Acta Vulcanol., 16(1-2), 9-20.

Cherepanov, G., and I. E. Esparragoza (2008), A fracture-entrainment model for snow avalanches, J. Glaciol., 54(184), 182-188, doi:10.3189/ 002214308784409071.

Christen, M., P. Bartelt, and J. Kowalski (2010a), Back calculation of the In den Arelen avalanche with RAMMS: Interpretation of model results, Ann. Glaciol., 51(54), 161-168, doi:10.3189/172756410791386553.

Christen, M., J. Kowalski, and P. Bartelt (2010b), RAMMS: Numerical simulation of dense snow avalanches in three-dimensional terrain, Cold Reg. Sci. Technol., 63, 1-14, doi:10.1016/j.coldregions.2010.04.005.

Crosta, G. B., H. Chen, and D. F. Lee (2004), Replay of the 1987 Val Pola Landslide, Italian Alps, Geomorphology, 60, 127-146, doi:10.1016/j. geomorph.2003.07.015.

Crosta, G. B., P. Frattini, and N. Fusi (2007), Fragmentation in the Val Pola rock avalanche, Italian Alps, J. Geophys. Res., 112, F01006, doi:10.1029/2005JF000455.

Crosta, G. B., S. Imposimato, and D. Roddeman (2009), Numerical modelling of entrainment/deposition in rock and debris-avalanches, Eng. Geol. Amsterdam, 109, 135-145, doi:10.1016/j.enggeo.2008.10.004.

Davies, M. C. R., O. Hamza, and C. Harris (2001), The effect of rise in mean annual temperature on the stability of rock slopes containing icefilled discontinuities, Permafrost Periglacial Processes, 12, 137-144, doi:10.1002/ppp.378.

Davies, T. R. H., and M. J. McSaveney (1999), Runout of dry granular avalanches, Can. Geotech. J., 36, 313-320, doi:10.1139/cgj-36-2-313.

Davies, T. R. H., M. J. McSaveney, and A. M. Deganutti (2007), Dynamic fragmentation causes low rock-on-rock friction, paper presented at 1st Canada-U.S. Rock Mechanics Symposium, Can. Rock Mech. Assoc., Vancouver, 27-31 May.

Deline, P. (2001), Recent Brenva rock avalanches (Valley of Aosta): New chapter in an old story?, Geogr. Fis. Din. Quat., 5, 55-63.

Deparis, J., D. Jongmans, F. Cotton, L. Baillet, F. Thouvenot, and D. Hantz (2008), Analysis of rock-fall and rock-fall avalanche seismograms in the French Alps, Bull. Seismol. Soc. Am., 98(4), 1781-1796, doi:10.1785/ 0120070082 .

Detterman, R. L., and B. L. Reed (1980), Stratigraphy, structure, and economic geology of the Iliamna Quadrangle, Alaska, U.S. Geol. Surv. Bull., $1368-B, 86 \mathrm{pp}$.

Evans, S. G., and J. J. Clague (1988), Catastrophic rock avalanches in glacial environments, Proceedings of the 5th International Symposium on Land- slides, Lausanne, Switzerland, 10-15 July 1988, vol. 2, pp. 1153-1158, A. A. Balkema, Rotterdamn, Netherlands.

Evans, S. G., and J. J. Clague (1998), Rock avalanche from Mount Munday, Waddington Range, British Columbia, Canada, Landslide News, 11, 23-25.

Evans, S. G., N. F. Bishop, L. F. Smoll, P. Valderrama Murillo, K. B. Delaney, and A. Oliver-Smith (2009a), A re-examination of the mechanism and human impact of catastrophic mass flows originating on Nevado Huascarán, Cordillera Blanca, Peru in 1962 and 1970, Eng. Geol. Amsterdam, 108(1-2), 96-118, doi:10.1016/j.enggeo.2009.06.020.

Evans, S. G., O. V. Tutubalina, V. N. Drobyshev, S. S. Chernomorets, S. McDougall, D. Petrakov, and O. Hungr (2009b), Catastrophic detachment and high-velocity long-runout flow of Kolka Glacier, Caucasus Mountains, Russia in 2002, Geomorphology, 105, 314-321, doi:10.1016/j.geomorph.2008.10.008

Fagents, S. A., and S. M. Baloga (2006), Toward a model for the bulking and debulking of lahars, J. Geophys. Res., 111, B10201, doi:10.1029/ 2005JB003986.

Farr, T. G., et al. (2007), The shuttle radar topography mission, Rev. Geophys., 45, RG2004, doi:10.1029/2005RG000183

Favreau, P., A. Mangeney, A. Lucas, N. M. Shapiro, G. B. Crosta, F. Bouchut, and O. Hungr (2009), Numerical modeling of landslide generated seismic waves, Eos Trans. AGU, 90(52), Fall Meet. Suppl., Abstract S24A-04.

Fischer, L., and C. Huggel (2008), Methodical design for stability assessments of permafrost affected high-mountain rock walls, in Proceedings of the Ninth International Conference on Permafrost, Fairbanks, Alaska, 29 June-3 July 2008, vol. 1, edited by D. L. Kane and K. M. Hinkel, pp. 439-444, Univ. of Alaska Fairbanks, Fairbanks, Alaska.

Giani, G. P., S. Silvano, and G. Zanon (2001), Avalanche of 18 January 1997 on Brenva glacier, Mont Blanc Group, Western Italian Alps: An unusual process of formation, Ann. Glaciol., 32(1), 333-338, doi:10.3189/ 172756401781819157.

Gruber, S., and W. Haeberli (2007), Permafrost in steep bedrock slopes and its temperature-related destabilization following climate change, J. Geophys. Res., 112, F02S18, doi:10.1029/2006JF000547.

Haeberli, W., and R. Hohmann (2008), Climate, glaciers and permafrost in the Swiss Alps 2050: Scenarios, consequences and recommendations, in Proceedings of the Ninth International Conference on Permafrost, Fairbanks, Alaska, 29 June-3 July 2008, vol. 1, edited by D. L. Kane and K. M. Hinkel, pp. 607-612, Univ. of Alaska Fairbanks, Fairbanks, Alaska.

Haeberli, W., C. Huggel, A. Kääb, S. Zgraggen-Oswald, A. Polkvoj, I. Galushkin, I. Zotikov, and N. Osokin (2004), The Kolka-Karmadon rock/ice slide of 20 September 2002: An extraordinary event of historical dimensions in North Ossetia, Russian Caucasus, J. Glaciol., 50(171), 533-546, doi:10.3189/172756504781829710.

Hewitt, K. (1999), Quaternary moraines vs catastrophic rock avalanches in the Karakoram Himalaya, Northern Pakistan, Quat. Res., 51(3), 220-237, doi:10.1006/qres.1999.2033.

Hewitt, K. (2009), Rock avalanches that travel onto glaciers and related developments, Karakoram Himalaya, Inner Asia, Geomorphology, 103 , 66-79, doi:10.1016/j.geomorph.2007.10.017.

Hsu, L., W. E. Dietrich, and L. S. Sklar (2008), Experimental study of bedrock erosion by granular flows, J. Geophys. Res., 113, F02001, doi:10.1029/2007JF000778

Huggel, C. (2009), Recent extreme slope failures in glacial environments: Effects of thermal perturbation, Quat. Sci. Rev., 28, 1119-1130, doi:10.1016/j.quascirev.2008.06.007.

Huggel, C., S. Zgraggen-Oswald, W. Haeberli, A. Kääb, A. Polkvoj, I. Galushkin, and S. G. Evans (2005), The 2002 rock/ice avalanche at Kolka/Karmadon, Russian Caucasus: Assessment of extraordinary avalanche formation and mobility, and application of QuickBird satellite imagery, Nat. Hazard. Earth Syst. Sci., 5, 173-187, doi:10.5194/nhess5-173-2005

Huggel, C., J. Caplan-Auerbach, C. F. Waythomas, and R. L. Wessels (2007), Monitoring and modeling ice-rock avalanches from ice-capped volcanoes: A case study of frequent large avalanches on Iliamna Volcano, Alaska, J. Volcanol. Geotherm. Res., 168(1-4), 114-136, doi:10.1016/j. jvolgeores.2007.08.009

Huggel, C., S. Gruber, J. Caplan-Auerbach, R. L. Wessels, and B. F. Molnia (2008a), The 2005 Mt. Steller, Alaska, rock-ice avalanche: What does it tell us about large slope failures in cold permafrost?, in Proceedings of the Ninth International Conference on Permafrost, Fairbanks, Alaska, 29 June-3 July 2008, vol. 1, edited by D. L. Kane and K. M. Hinkel, pp. 747-752, Univ. of Alaska Fairbanks, Fairbanks, Alaska.

Huggel, C., J. Caplan-Auerbach, and R. L. Wessels (2008b), Recent extreme avalanches: Triggered by climate change?, Eos Trans. $A G U$, 89(47), doi:10.1029/2008EO470001.

Hungr, O., and S. G. Evans (1996), Rock avalanche runout prediction using a dynamic model, in Proceedings of the 7th International Symposium on 
Landslides, Trondheim, Norway, 17-21 June 1996, vol. 1, edited by K. Senneset, pp. 223-238, A. A. Balkema, Rotterdamn, Netherlands.

Hungr, O., and S. G. Evans (2004), Entrainment of debris in rock avalanches: An analysis of a long run-out mechanism, Geol. Soc. Am. Bull., 116(9), 1240-1252, doi:10.1130/B25362.1.

Hungr, O., and S. McDougall (2009), Two numerical models for landslide dynamic analysis, Comput. Geosci., 35, 978-992, doi:10.1016/j.cageo. 2007.12.003

Iverson, R. M., and R. P. Denlinger (2001), Flow of variably fluidized granular masses across three-dimensional terrain: 1 . Coulomb mixture theory, J. Geophys. Res., 106(B1), 537-552, doi:10.1029/2000JB900329.

Kääb, A., et al. (2005), Remote sensing of glacier- and permafrost-related hazards in high mountains: An overview, Nat. Hazards Earth Syst. Sci., 5, 527-554, doi:10.5194/nhess-5-527-2005.

Kanamori, H., and J. W. Given (1982), Analysis of long-period seismic waves excited by the May 18, 1980, eruption of Mount St. Helens: A terrestrial monopole?, J. Geophys. Res., 87(B7), 5422-5432, doi:10.1029/ JB087iB07p05422.

Kawakatsu, H. (1989), Centroid single force inversion of seismic waves generated by landslides, J. Geophys. Res., 94(B9), 12,363-12,374, doi:10.1029/JB094iB09p12363.

Kelfoun, K., and T. H. Druitt (2005), Numerical modeling of the emplacement of Socompa rock avalanche, Chile, J. Geophys. Res., 110, B12202, doi:10.1029/2005JB003758.

Kern, M., P. Bartelt, B. Sovilla, and O. Buser (2009), Measured shear rates in dry and wet snow avalanches, J. Glaciol., 55(190), 327-338, doi:10.3189/002214309788608714.

Körner, H. J. (1976), Reichweite und Geschwindigkeit von Bergstürzen und Fliessschneelawinen, Rock Mech., 8(4), 225-256, doi:10.1007/ BF01259363.

Körner, H. J. (1983), Zur Mechanik der Bergsturzströme vom Huascarán, Perú, in Die Berg-und Gletscherstürze vom Huascarán, Cordillera Blanca, Perú, edited by G. Patzelt, pp. 71-110, Wagner Univ. Press, Innsbruck, Austria.

Korup, O. (2005), Large landslides and their effect on sediment flux in South Westland, New Zealand, Earth Surf. Processes Landforms, 30, 305-323, doi:10.1002/esp.1143.

Kotlyakov, V. M., O. V. Rototaeva, and G. A. Nosenko (2004), The September 2002 Kolka Glacier catastrophe in north Ossetia, Russian Federation: Evidence and analysis, Mt. Res. Dev., 24(1), 78-83, doi:10.1659/ 0276-4741(2004)024[0078:TSKGCI]2.0.CO;2.

Kowalski, J. (2008), Two-phase modeling of debris flows, Ph.D. thesis, 136 pp., Swiss Fed. Inst. of Technol., ETH Zurich, Zurich, Switzerland.

Lipovsky, P. S., et al. (2008), The July 2007 rock and ice avalanches at Mount Steele, St. Elias Mountains, Yukon, Canada, Landslides, 5(4), 445-455, doi:10.1007/s10346-008-0133-4.

Locat, P., R. Couture, S. Leroueil, J. Locat, and M. Jaboyedoff (2006), Fragmentation energy in rock avalanches, Can. Geotech. J., 43, 830-851, doi:10.1139/T06-045.

Mangeney, A., L. S. Tsimring, D. Volfson, I. S. Aranson, and F. Bouchut (2007), Avalanche mobility induced by the presence of an erodible bed and associated entrainment, Geophys. Res. Lett., 34, L22401, doi:10.1029/2007GL031348.

Margreth, S., and M. Funk (1999), Hazard mapping for ice and combined snow/ice avalanches-Two case studies from the Swiss and Italian Alps, Cold Reg. Sci. Technol., 30(1-3), 159-173, doi:10.1016/S0165-232X (99)00027-0.

McDougall, S., and O. Hungr (2005), Dynamic modelling of entrainment in rapid landslides, Can. Geotech. J., 42, 1437-1448, doi:10.1139/t05-064.

McSaveney, M. J. (2002), Recent rockfalls and rock avalanches in Mount Cook National Park, New Zealand, in Catastrophic Landslides: Effects, Occurrence, and Mechanism, Rev. Eng. Geol., vol. 15, edited by S. G. Evans and J. V. DeGraff, pp. 35-70, Geol. Soc. of Am., Boulder, Colo.

McSaveney, M. J., and G. Downes (2002), Application of landslide seismology to some New Zealand rock avalanches, in Landslides, edited by J. Rybáŕ, J. Stemberk, and P. Wagner, pp. 649-654, Swets Zeitlinger, Lisse, Netherlands.

Perla, R., T. T. Cheng, and D. M. McClung (1980), A two-parameter model of snow-avalanche motion, J. Glaciol., 26(94), 197-207.
Pirulli, M., and G. Sorbino (2008), Assessing potential debris flow runout: A comparison of two simulation models, Nat. Hazards Earth Syst. Sci., 8, 961-971, doi:10.5194/nhess-8-961-2008.

Plafker, G., and G. E. Ericksen (1978), Nevados Huascarán avalanches, Peru, in Rockslides and Avalanches: 1. Natural Phenomena, edited by B. Voight, pp. 277-314, Elsevier, Amsterdam.

Preuth, T., P. Bartelt, O. Korup, and B. W. McArdell (2010), A random kinetic energy model for rock avalanches: Eight case studies, J. Geophys. Res., 115, F03036, doi:10.1029/2009JF001640.

Rabus, B., M. Eineder, A. Roth, and R. Bamler (2003), The shuttle radar topography mission-A new class of digital elevation models acquired by spaceborne radar, ISPRS J. Photogramm. Remote Sens., 57, 241-262, doi:10.1016/S0924-2716(02)00124-7.

Sabot, F., M. Naaim, F. Granada, E. Suriñach, P. Planet, and G. Furdada (1998), Study of avalanche dynamics by seismic methods, image-processing techniques and numerical models, Ann. Glaciol., 26, 319-323.

Salm, B. (1993), Flow, flow transition and runout distances of flowing avalanches, Ann. Glaciol., 18, 221-226.

Schneider, D., H. Delgado Granados, C. Huggel, and A. Kääb (2008), Assessing lahars from ice-capped volcanoes using ASTER satellite data, the SRTM DTM and two different flow models: Case study on Iztaccíhuat (Central Mexico), Nat. Hazards Earth Syst. Sci., 8(3), 559-571, doi:10.5194/nhess-8-559-2008.

Schneider, J. F. (2006), Risk assessment of remote geohazards in Western Pamir, GBAO, Tajikistan, in Proceedings of the International Conference on High Mountaing Hazard Prevention, Vladikavkaz-Moscow, June 23-26, 2004, pp. 252-267, Swiss Agency for Dev. and Coop., Vladikavkaz, Russia.

Sosio, R., G. B. Crosta, and O. Hungr (2008), Complete dynamic modeling calibration for the Thurwieser rock avalanche (Italian Central Alps), Eng. Geol. Amsterdam, 100, 11-26, doi:10.1016/j.enggeo.2008.02.012.

Sovilla, B., P. Burlando, and P. Bartelt (2006), Field experiments and numerical modeling of mass entrainment in snow avalanches, J. Geophys. Res., 111, F03007, doi:10.1029/2005JF000391.

Sovilla, B., S. Margreth, and P. Bartelt (2007), On snow entrainment in avalanche dynamics calculations, Cold Reg. Sci. Technol., 47(1-2), 69-79, doi:10.1016/j.coldregions.2006.08.012.

Suriñach, E., F. Sabot, G. Furdada, and J. M. Vilaplana (2000), Study of seismic signals of artificially released snow avalanches for monitoring purposes, Phys. Chem. Earth, 25(9), 721-727.

Suriñach, E., G. Furdada, F. Sabot, B. Biescas, and J. M. Vilaplana (2001), On the characterization of seismic signals generated by snow avalanches for monitoring purposes, Ann. Glaciol., 32, 268-274, doi:10.3189/ 172756401781819634.

Suriñach, E., I. Vilajosana, G. Khazaradze, B. Biescas, G. Furdada, and J. M. Vilaplana (2005), Seismic detection and characterization of landslides and other mass movements, Nat. Hazards Earth Syst. Sci., 5(6), 791-798, doi:10.5194/nhess-5-791-2005.

Trabant, D. C. (1999), Perennial snow and ice volumes on Iliamna volcano, Alaska, estimated with ice radar and volume modeling, Water Res. Invest. Rep. 99-4176, U.S. Geol. Surv., Anchorage, Alaska.

Voellmy, A. (1955), Über die Zerstörungskraft von Lawinen, Schweiz. Bauztg., 73(15), 212-217.

Waythomas, C. F., T. P. Miller, and J. E. Beget (2000), Record of Late Holocene debris avalanches and lahars at Iliamna Volcano, Alaska, J. Volcanol. Geotherm. Res., 104(1-4), 97-130, doi:10.1016/S03770273(00)00202-X.

Weichert, D., R. B. Horner, and S. G. Evans (1994), Seismic signatures of landslides: The 1990 Brenda mine collapse and the 1965 Hope rockslides, Bull. Seismol. Soc. Am., 84(5), 1523-1532.

P. Bartelt and M. Christen, WSL Institute for Snow and Avalanche Research SLF, Flüelastr. 11, Davos-Dorf CH-7260, Switzerland.

J. Caplan-Auerbach, Geology Department, Western Washington University, 516 High St., MS 9080, Bellingham, WA 98225, USA.

C. Huggel and D. Schneider, Department of Geography, University of Zurich, Winterthurerstr. 190, Zurich $\mathrm{CH}-8057$, Switzerland. (demian. schneider@geo.uzh.ch)

B. W. McArdell, Swiss Federal Institute for Forest, Snow and Landscape Research WSL, Zuercherstr. 111, Birmensdorf $\mathrm{CH}-8903$, Switzerland. 